\title{
Production of recombinant proteins in E. coli by the heat inducible expression system based on the phage lambda $\mathrm{pL}$ and/or pR promoters
}

\author{
Norma A Valdez-Cruz ${ }^{1}$, Luis Caspeta' , Néstor O Pérez², Octavio T Ramírez', Mauricio A Trujillo-Roldán ${ }^{3 *}$
}

\begin{abstract}
The temperature inducible expression system, based on the $\mathrm{pL}$ and/or $\mathrm{pR}$ phage lambda promoters regulated by the thermolabile cl857 repressor has been widely use to produce recombinant proteins in prokariotic cells. In this expression system, induction of heterologous protein is achieved by increasing the culture temperature, generally above $37^{\circ} \mathrm{C}$. Concomitant to the overexpression of heterologous protein, the increase in temperature also causes a variety of complex stress responses. Many studies have reported the use of such temperature inducible expression system, however only few discuss the simultaneous stress effects caused by recombinant protein production and the up-shift in temperature. Understanding the integral effect of such responses should be useful to develop improved strategies for high yield protein production and recovery. Here, we describe the current status of the heat inducible expression system based on the $\mathrm{pL}$ and/or $\mathrm{pR} \lambda$ phage promoters, focusing on recent developments on expression vehicles, the stress responses at the molecular and physiological level that occur after heat induction, and bioprocessing factors that affect protein overexpression, including culture operation variables and induction strategies.
\end{abstract}

\section{Heat induction: A compromise between recombinant protein production and stress}

E. coli expression systems have been the preferred option for producing many recombinant proteins in high quantities and low production costs [1-6]. Among the underlying reasons for such a widespread use of $E$. coli is the availability of a variety of strong inducible promoters [7]. The promoters commonly employed for heterologous protein expression require the addition of an inducer molecule, the depletion or addition of a nutrient, or a shift in a physical or physicochemical factor, such as $\mathrm{pH}$ [4]. Yet, each option can present different shortcomings. For instance chemical inducers, such as IPTG and antibiotics, can be expensive and toxic, and their presence in either the final product or in the waste effluents of the bioprocess represent a hazard that must be eliminated $[8,9]$. Accordingly, additional controls and downstream operations may be required to remove chemical inducers, particularly from pharmaceutical-grade proteins and

\footnotetext{
* Correspondence: maurotru@biomedicas.unam.mx

${ }^{3}$ Unidad de Bioprocesos, Departamento de Inmunología, Instituto de Investigaciones Biomédicas, Universidad Nacional Autónoma de México, A.P. 70228, México, D.F., C.P. 04510, México
}

products intended for human use, complicating the bioprocess and increasing its cost [10]. In systems based on nutrient exhaustion, such as depletion of an amino acid from the culture broth, starvation can affect cell metabolism or synthesis of the recombinant protein $[11,12]$ and a precise control of the induction timing is difficult. In the case of $\mathrm{pH}$-inducible expression systems, few vectors are available, characterization studies are still insufficient, and $\mathrm{pH}$ for induction can depart from the optimal $\mathrm{pH}$ for physiological conditions [13]. Many of the drawbacks mentioned can be overcome when using the thermoregulated expression system reviewed here.

The thermo-regulated expression system has been successfully used for the production of many recombinant proteins and peptides since it relies on a strong and finely regulated promoter, and the use of special media, toxic or expensive chemical inducers is avoided [14]. Furthermore, culture handling and contamination risks are minimized, as temperature in fermentors can be readily modified by external means. All these features are relevant conditions when producing therapeutic recombinant proteins. In addition, the system is easily scalable, although heat transfer limitations of

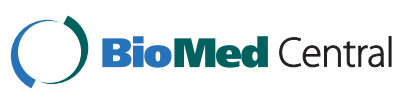

(c) 2010 Valdez-Cruz et al; licensee BioMed Central Ltd. This is an Open Access article distributed under the terms of the Creative Commons Attribution License (http://creativecommons.org/licenses/by/2.0), which permits unrestricted use, distribution, and reproduction in any medium, provided the original work is properly cited. 
large-scale bioreactors should be taken in consideration, as heating rate will decrease as culture volume increases [15].

The thermo-regulated expression system is based on the insertion of the gene of interest into different vectors containing the strong major leftward $(\mathrm{pL})$ and/or rightward $(\mathrm{pR})$ promoters. The gene cloned downstream of the $\lambda$ promoters can then be efficiently regulated by the mutant thermolabile cI857 repressor of bacteriophage $\lambda[10,16]$. Gene expression is inhibited at culture temperatures below $37^{\circ} \mathrm{C}$ (normally in the range of $28-32^{\circ} \mathrm{C}$ ) whereas transcription by the host RNA polymerase ensues upon inactivation of the mutant repressor by increasing the temperature above $37^{\circ} \mathrm{C}$ (Figure 1) [16]. Similarly to what occurs in all other expression systems, the production of heterologous protein causes important stresses and metabolic unbalances. For instance, the overproduction of recombinant protein can trigger the heat shock like response, stringent response and the SOS response, and can result in a metabolic burden to the cells $[17,18]$. As a consequence, specific grow rate will in general decrease, and ribosome degradation [19] and alterations in the central carbon metabolism [20] can occur. Altogether, these effects can alter the quantity and quality of the foreign protein produced $[18,21,22]$. However, in contrast to other expression systems, heat induction also triggers the heatshock response (HSR) that is controlled by the alternative sigma factor $\sigma 32$ ( $r p o H$ gene product) [23,24]. The HSR includes a rapid and selective synthesis of heat-shock proteins (hsp) soon after temperature increases. Thereafter, an adaptation period occurs with a lower rate of protein synthesis that latter reaches a new steady-state level. The hsp serve as chaperones and proteases involved in folding, degradation, and proper feedback regulation of the HSR $[24,25]$. In addition to the synthesis of hsp, the physiological response of $E$. coli after a heat shock also includes the temporary decrease in growth rate and changes in cell membranes due to modification of the ratio of lipids and integral membrane proteins [26].

Many reports exist of recombinant protein production under the heat-inducible system, and many other separate studies also exist of the HSR. Nonetheless, activation and regulation of the HSR in a thermoinduced recombinant protein productive system has been scarcely studied. This review focuses on the regulation of the inducible expression $\lambda \mathrm{pL} / \mathrm{pR}$-cI857 system, describing the molecular and physiological changes on the host cells caused by temperature associated stresses during thermoinduction, and the relation of such effects with the productivity and quality of the recombinant proteins.

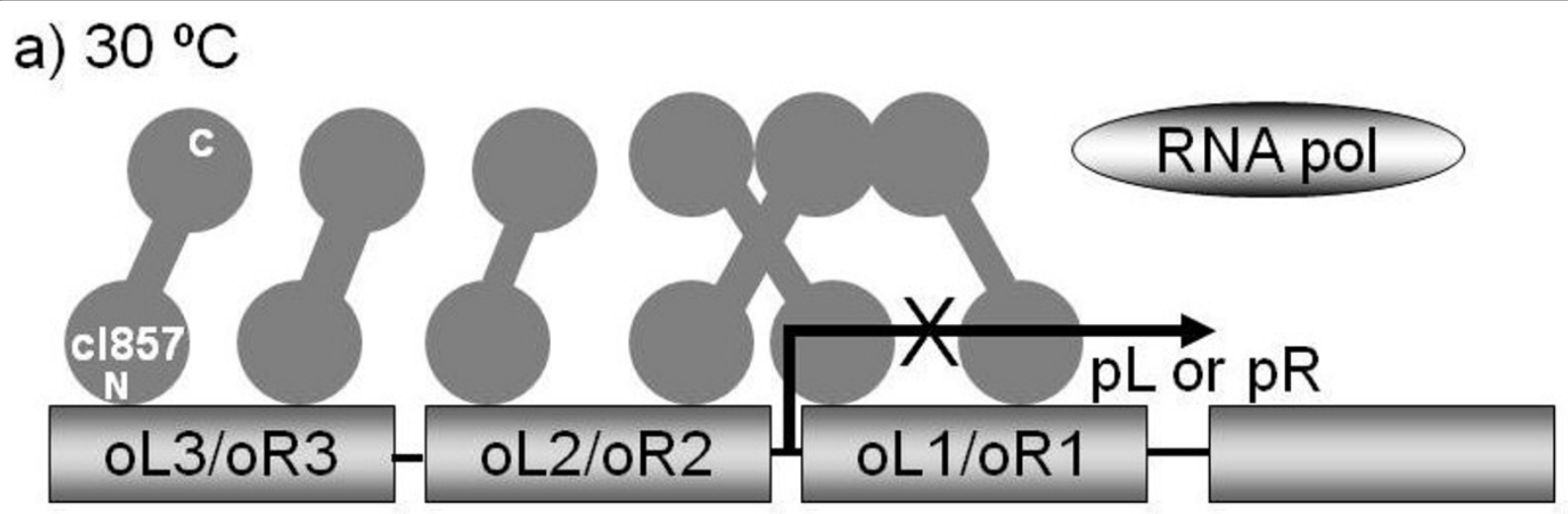

b) $42{ }^{\circ} \mathrm{C}$
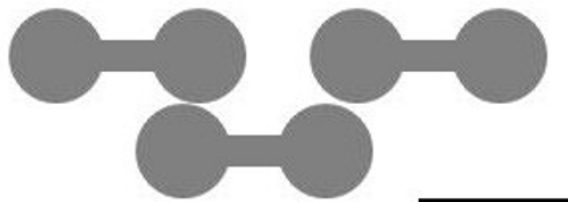

\section{Transcription}

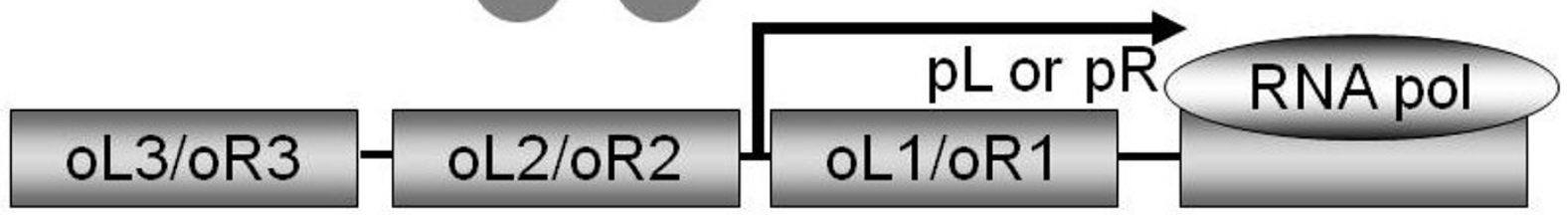

Figure 1 Representation of the $\mathrm{pL} / \mathrm{pR}$ promoters controlled by the $\mathbf{c l 8 5 7}$ repressor. The $\mathrm{cl} 857$ interacts with three operator domains (oL3/ oR3, oL2/OR2, and oL1/OR1), repressing transcription. The heterologous gene is localized downstream from the pL or pR promoters. a) The cl857 forms dimers that bind to the oL or oR region and block transcription by RNA polymerase. b) The interaction of cl857 with oL or oR regions, is released up to $37^{\circ} \mathrm{C}$, permitting transcription by RNA polymerase. 


\section{Molecular Biology of $\lambda \mathrm{pL} / \mathrm{pR}-\mathrm{cl} 857$}

Lambda phage elements like those that comprise the plasmids $\lambda \mathrm{pL} / \mathrm{pR}$-cI857 and their regulation have been used for the production of foreign products in $E$ coli [27].

\section{Lambda phage and the important elements for the $\lambda \mathrm{pL} /$ pR expression system}

The lambda phage is a dsDNA virus that infects $E$. coli and presents two lifecycle pathways [28]. The first, called the lytic pathway, consists of infection, rapid replication, assembling, and release of viral particles that can start a new cycle by infecting other hosts [27]. The lytic cycle seems to be favored when the host is healthy. The second is the lysogenic pathway, in which the lambda phage DNA is inserted into the host chromosome and is replicated with the rest of the bacterial DNA, remaining inactive in latent form $[27,29]$. The $\lambda$ phage circular genome is formed by 48,502 base pairs that code for lytic genes, including the early lytic genes expressed from the $\mathrm{pL}$ and $\mathrm{pR}$ promoters, the late lytic genes under the $\mathrm{pR}$ ' promoter, and the lysogenic genes expressed under the promoter for repressor maintenance (pRM) [27].

Gene regulation in bacteriophage $\lambda$ is controlled by a key component, the $\lambda \mathrm{cI}$ repressor that acts as a genetic switch between the lysogenic growth and lytic development [30,31]. cI is a protein formed by 236 amino acids distributed in two domains. In a lysogenic state, the host is not lysed because cI repressor prevents transcription of $\lambda$ lytic genes. During lysogenic growth, the cI dimer repressor binds in a cooperative form, by proteinprotein interactions of their C-terminal domains [32,33], to the operator regions oR (oR1 and oR2) and oL (oL1, $\mathrm{oL} 2$, and oL3), blocking the $\mathrm{pR}$ and $\mathrm{pL}$ promoters, respectively [34]. Moreover, cI binding allows the transcription from pRM in a concentration-dependent manner $[29,31,35]$. cI can also repress pRM in a cooperative manner by binding to oR3 after oL3 and oR3 are juxtaposed during DNA loop formation mediated by octamerization of cI dimers on oR1, oR2, oL1, and oL2 [34]. However, cI concentration must be 5 -times higher than that found normally in the lysogenic state to occupy $50 \%$ of oR3, otherwise, occupancy in the lysogen is less than $20 \%[36,37]$. Accordingly, $\lambda$ cI repressor has little negative autoregulation and physiological effects in the lysogenic state $[37,38]$. The presence of cI alone can maintain the lysogenic state, however a switch to the lytic pathway occurs when the host SOS response is triggered by DNA damage, which in turn induces the expression of the protein Rec-A that activates cI autocleavage [39-41].
Regulation of the $\lambda \mathrm{pL} / \mathrm{pR}-\mathrm{cl} 857$ system by temperature or other inducers

In 1966 Margaret Lieb identified $\lambda$ lytic temperature sensitive (Ts) mutants that were induced by temperature up-shifts [42]. One of these mutants is cI857, which has the substitution of Ala66 by Thr in the amino-terminal region of the repressor. This mutant retains wild-type properties at low temperature, but is unstable when temperature is elevated [43]. Such finding opened the possibility for physically regulating the tight control switch of $\mathrm{cI}$ binding affinity to $\lambda \mathrm{pL} / \mathrm{pR}$ promoters and constituted the foundation for its biotechnological exploitation within expression systems for heterologous protein production in $E$. coli (Figure 1). The recombinant proteins initially expressed in the $\lambda \mathrm{pL} / \mathrm{pR}-\mathrm{cI} 857$ system were those from E. coli [44-47], phages [48,49], and virus [50]. Soon after, the attention for this expression system broaden to other proteins of biotechnological interest, in particular for the production of human therapeutic recombinant protein such as $\beta$ interferon, insulin, recombinant human growth hormone ( $\mathrm{rHGH})$, and tumor necrosis factor [7,10,51-55] (Table 1).

The thermoinduced expression system has been improved throughout the years (Table 1). One of the earliest remarkable advances was the overproduction of the cI repressor by construction of plasmids bearing the lac operon promoter adjacent to the cI repressor gene [56]. Latter on, the first expression vectors using the $\mathrm{pL}$ promoter were described and shown to yield recombinant protein at 2.0 to $6.6 \%$ of total protein [44,57-59]. Some years latter, recombinant protein yields reached almost $30 \%$ of total protein in an E. coli strain harboring a pL plasmid and a chromosomal defective prophage with a copy of cI857 [60]. Although Remaut et al. [60] used a similar strategy than Bernard et al. [57], they were able to attain higher production of recombinant protein by decreasing the distance between the pL promoter and the cloned gene. By 1983, an improved plasmid vector that increased productivity was reported [59]. It included the use of temperature-regulated runaway replication that allowed the increase in plasmid copy number and repression release after temperature up-shift. A second improvement, that made possible the use of practically any E. coli strain with this system, consisted in the use of a compatible plasmid encoding cI857 [61] (Table 1). Other researchers developed an expression vector that included the $\mathrm{pL}$ promoter and the cI857 gene in the same plasmid construction [58]. Several other improvements to the expression vectors have been described, including synthetic ribosome-binding sites and suitable poly-linkers to allow the cloning of any gene to be expressed $[62,63]$. Recently, mutations in 
Table 1 Summary of reported yields obtained with the $\lambda \mathrm{pL} / \mathrm{pR} / \mathrm{cl} 857$ thermoinduced expression system.

\begin{tabular}{|c|c|c|c|c|c|}
\hline Protein & Plasmid & Culture conditions; induction strategy & Production & System & Ref. \\
\hline \multicolumn{6}{|c|}{ Recombinant protein localized in cytoplasm } \\
\hline UVRA & pGHY5003 & $\mathrm{BC} ; 30$ to $42^{\circ} \mathrm{C}$ & $7 \%$ TCP & $\lambda \mathrm{pl}, \mathrm{cl} 857$ & [44] \\
\hline IFN- $\beta$ & pPLc245-HFIF25 & $\mathrm{BC} ; 28$ to $42^{\circ} \mathrm{C}$ & $4 \%$ TCP & $\lambda \mathrm{pL} / \mathrm{cl} 857$ & [61] \\
\hline GXP & pHEGPT & $\mathrm{BC}, \mathrm{SF} ; 30$ to $42^{\circ} \mathrm{C}$ & $5 \% \mathrm{TCP}$ & $\lambda \mathrm{pL} / \mathrm{cl} 857$ & {$[58]$} \\
\hline IHF $\alpha, \beta$ & $\begin{array}{l}\text { pPlhima-1, } \\
\text { pPLhipohim A-s }\end{array}$ & $\mathrm{BC} ; 31$ to $42^{\circ} \mathrm{C}$ & $3 \mathrm{mg} / \mathrm{L}$ & $\lambda \mathrm{pL} / \mathrm{cl} 857$ & [169] \\
\hline rpGH & p-LARpGH & $\mathrm{BC}, \mathrm{SF} ; 30$ to $42^{\circ} \mathrm{C}(3-4 \mathrm{~h})$, temp reached in $5-8 \mathrm{~min}$ & $15 \%$ TCP & $\lambda \mathrm{pL} / \mathrm{lc} 1857$ & [170] \\
\hline $\mathrm{rpGH}$ & p-LARpGH & $\mathrm{FB} ; 30$ to $42^{\circ} \mathrm{C}$ & $20 \%$ TCP & $\lambda \mathrm{pL} / \mathrm{lc|} 857$ & [170] \\
\hline$\beta$-gal & pJLACZ & $\mathrm{CC} ; 28$ to $40^{\circ} \mathrm{C}$ & $\begin{array}{l}3,037 \mathrm{U} / \mathrm{ml} / \\
\mathrm{OD}\end{array}$ & $\lambda \mathrm{pL} \mathrm{cl857}$ & {$[16]$} \\
\hline$\beta$-gal & pJLACZ & CC; 28 to $42^{\circ} \mathrm{C}$ & $\begin{array}{l}7,327 \mathrm{U} / \mathrm{ml} / \\
\mathrm{OD}\end{array}$ & $\lambda \mathrm{pL}$ cl857 & [16] \\
\hline SpA- $\beta$-gal & & $\mathrm{BC} ; 30$ to $40^{\circ} \mathrm{C}$ & $6.2 \mathrm{~g} / \mathrm{L}$ & $\lambda p R$ & [65] \\
\hline SpA- $\beta$-gal & & $\mathrm{FB} ; 30$ to $40^{\circ} \mathrm{C}$ & $19.2 \mathrm{~g} / \mathrm{L}$ & $\lambda p R$ & [65] \\
\hline$\beta$-gal & $\begin{array}{l}\text { PACYC177; } \\
\text { pRSET- } \\
\text { lacZ }\end{array}$ & $\mathrm{BC}, \mathrm{SF} ; 30$ to $42^{\circ} \mathrm{C}(2 \mathrm{~min})$, reducing to $37^{\circ} \mathrm{C}$ & $23500 \mathrm{U}$ & $\lambda \mathrm{pL} / \mathrm{cl} 857$ & [171] \\
\hline$\beta$-gal & $\begin{array}{l}\text { pACYC177; } \\
\text { pRSET- } \\
\text { lacZ }\end{array}$ & $\mathrm{BC}$, SF- $\mathrm{FB} ; 30$ to $42^{\circ} \mathrm{C}$ (2 $\left.\mathrm{min}\right)$, reducing to $37^{\circ} \mathrm{C}$ & $23000 \mathrm{U}$ & $\lambda \mathrm{pL} / \mathrm{cl} 857$ & [171] \\
\hline$\beta$-gal & $\begin{array}{l}\text { PACYC177; } \\
\text { pRSET- } \\
\text { lacZ }\end{array}$ & $\mathrm{FB} ; 30$ to $42^{\circ} \mathrm{C}(2 \mathrm{~min})$, reducing to $37^{\circ} \mathrm{C}$ & $\begin{array}{l}285000 \mathrm{U} \\
(0.95 \mathrm{~g} / \mathrm{L})\end{array}$ & $\lambda \mathrm{pL} / \mathrm{cl} 857$ & [171] \\
\hline Carbamoylase & $\begin{array}{l}\text { PTAH10; } \\
\text { pT-GroE }\end{array}$ & $\begin{array}{l}\mathrm{BC}, \mathrm{SF} ; 30 \text { to } 39^{\circ} \mathrm{C} \text { reached abruptly (10 to } 20 \mathrm{~min} \text { ), } \\
\text { decrease to } 37^{\circ} \mathrm{C}\end{array}$ & $\begin{array}{l}7 \mathrm{U} \\
(0.14 \mathrm{U} / \mathrm{mL})\end{array}$ & $\lambda$ pLpR, c1857-T7 RNA pol & {$[67]$} \\
\hline Carbamoylase & $\begin{array}{l}\text { PTAH10; } \\
\text { pT-GroE }\end{array}$ & $\mathrm{BC} ; 30-39^{\circ} \mathrm{C}(10$ to $20 \mathrm{~min})$, decrease to $37^{\circ} \mathrm{C}$ & $\begin{array}{l}1830 \mathrm{U} \\
(1.2 \mathrm{U} / \mathrm{mL})\end{array}$ & $\lambda \mathrm{pLpR}$, cl857-T7 RNA pol & {$[67]$} \\
\hline Carbamoylase & $\begin{array}{l}\text { PTAH10; } \\
\text { pT-GroE }\end{array}$ & $\mathrm{FB} ; 30$ to $39^{\circ} \mathrm{C}(10 \mathrm{~min})$, decrease to $37^{\circ} \mathrm{C}$ & $\begin{array}{l}14256 \mathrm{U} \\
(5.8 \mathrm{U} / \mathrm{mL})\end{array}$ & $\lambda p L p R$, cl857-T7 RNA pol & {$[67]$} \\
\hline TNF- $\alpha$ & pCY-TNF & $\mathrm{BC}, \mathrm{SF} ; 30$ to $42^{\circ} \mathrm{C}$ & $\begin{array}{l}12 \% \\
\text { soluble TCP }\end{array}$ & $\begin{array}{l}\lambda p R p L \\
\text { cl } 857\end{array}$ & [10] \\
\hline TNF- $\alpha$ & pCY-TNF & $\mathrm{BC}, 30$ to $42^{\circ} \mathrm{C}(6 \mathrm{~h})$ & $\begin{array}{l}11 \% \\
\text { soluble TCP }\end{array}$ & $\begin{array}{l}\lambda p R P L \\
\mathrm{Cl} 857\end{array}$ & {$[10]$} \\
\hline TRAIL & pBV-Trail & $\mathrm{FB} ; 30$ to $42^{\circ} \mathrm{C}(4 \mathrm{~h})$ & $1.4 \mathrm{~g} / \mathrm{L}$ & Temperature inducible & [172] \\
\hline GFP & pND-GFP & $\begin{array}{l}\mathrm{BC} ; 30 \text { to } 42^{\circ} \mathrm{C}(1 \mathrm{~h}) \\
\text { reducing to } 30^{\circ} \mathrm{C}\end{array}$ & $30 \mathrm{mg} / \mathrm{L}$ & $\lambda \mathrm{pL} / \mathrm{cl} 857$ & [137] \\
\hline GFP & pND-GFP & $\begin{array}{l}\mathrm{BC} ; 37 \text { to } 42^{\circ} \mathrm{C}(1 \mathrm{~h}) \\
\text { reducing to } 37^{\circ} \mathrm{C}\end{array}$ & $50 \mathrm{mg} / \mathrm{L}$ & $\lambda \mathrm{pL} / \mathrm{cl} 857$ & [137] \\
\hline GFP & pND-GFP & $\begin{array}{l}\mathrm{BC}, \mathrm{SF} ; 37 \text { to } 42^{\circ} \mathrm{C}(1 \mathrm{~h}) \\
\text { reducing to } 37^{\circ} \mathrm{C}\end{array}$ & $7 \mathrm{mg} / \mathrm{L}$ & $\lambda \mathrm{pL} / \mathrm{cl} 857$ & [137] \\
\hline GFP & pND-GFP & $\begin{array}{l}\mathrm{BC}, \mathrm{SF} ; 37 \text { to } 42^{\circ} \mathrm{C}(1 \mathrm{~h}) \text {, reduction to } 37^{\circ} \mathrm{C}(1 \mathrm{~h}) \text {, increasing } \\
\text { to } 42^{\circ} \mathrm{C}(1 \mathrm{~h}) \text {, reducing to } 37^{\circ} \mathrm{C}\end{array}$ & $68 \mathrm{mg} / \mathrm{L}$ & $\lambda \mathrm{pL} / \mathrm{cl} 857$ & [137] \\
\hline GFP & pND-GFP & $\begin{array}{l}\mathrm{BC}, \mathrm{SF} ; 30 \text { to } 42^{\circ} \mathrm{C}(1 \mathrm{~h}) \text {, reduction to } 30^{\circ} \mathrm{C}(1 \mathrm{~h}) \\
\text { increase to } 42^{\circ} \mathrm{C}(1 \mathrm{~h}) \text {, } \\
\text { decrease to } 30^{\circ} \mathrm{C}\end{array}$ & $45 \mathrm{mg} / \mathrm{L}$ & $\lambda \mathrm{pL} / \mathrm{cl} 857$ & [137] \\
\hline GFP & pND-GFP & $\begin{array}{l}\mathrm{FB} ; 30 \text { to } 42^{\circ} \mathrm{C}(30 \mathrm{~min}) \text {, decrease to } 30^{\circ} \mathrm{C} \text {, } \\
\text { increase to } 42^{\circ} \mathrm{C}(30 \mathrm{~min}) \text {, decrease to } 30^{\circ} \mathrm{C}\end{array}$ & $273 \mathrm{mg} / \mathrm{L}$ & $\lambda \mathrm{pL} / \mathrm{cl} 857$ & [137] \\
\hline \multicolumn{6}{|c|}{ IB localized in cytoplasm } \\
\hline $\mathrm{IFN}-\gamma$ & pPL-I & $\mathrm{BC}, \mathrm{SF} ; 28^{\circ} \mathrm{C}-42^{\circ} \mathrm{C}$ & $0.3 \mathrm{~g} / \mathrm{L}$ & $\lambda \mathrm{pL} / \mathrm{cl} 857$ & {$[52]$} \\
\hline IFN- $\gamma$ & pPL-1 & $\mathrm{FB} ; 28$ to $42^{\circ} \mathrm{C}$ & $7.43 \mathrm{~g} / \mathrm{L}$ & $\lambda \mathrm{pL} / \mathrm{cl} 857$ & {$[52]$} \\
\hline $\begin{array}{l}\text { Insulin A- } \\
\text { chain-Mut3sY }\end{array}$ & PMYW-A & $\mathrm{BC}, \mathrm{SF}: \mathrm{BL} 21 ; 30$ to $42^{\circ} \mathrm{C}$ & $30 \%$ TCP & $\lambda \mathrm{pl} / \mathrm{cl} 857$ & {$[53]$} \\
\hline $\begin{array}{l}\text { Insulin A- } \\
\text { chain-Mut3sY }\end{array}$ & PMYW-A & $\mathrm{FB}, \mathrm{HCDC} ; 30$ to $42^{\circ} \mathrm{C}$ & $13 \%$ TCP & $\lambda \mathrm{pl}, \mathrm{Ic|} 857$ & {$[53]$} \\
\hline $\begin{array}{l}\text { Insulin B- chain- } \\
\text { Mut3sY }\end{array}$ & PMYW-B & $\mathrm{FB}, \mathrm{HCDC} ; 30$ to $42^{\circ} \mathrm{C}$ & $\begin{array}{l}18 \% \mathrm{TCP} \\
(4.6 \mathrm{~g} / \mathrm{L})\end{array}$ & $\lambda \mathrm{pl}, \mathrm{Icl} 857$ & {$[53]$} \\
\hline IFN- $\alpha$ & pMYW-a & FB; 30 to $42^{\circ} \mathrm{C}$ & $4 \mathrm{~g} / \mathrm{L}$ & $\lambda p l,|c| 857$ & [7] \\
\hline
\end{tabular}


Table 1: Summary of reported yields obtained with the $\lambda \mathrm{pL} / \mathrm{pR} / \mathrm{cl} 857$ thermoinduced expression system. (Continued)

\begin{tabular}{|c|c|c|c|c|c|}
\hline rhBMP-2 & PCYTEXP3-BMP-2 & $\mathrm{BC}$, SF 30 to $42^{\circ} \mathrm{C}$ & $25 \%$ TCP & $\lambda \mathrm{pL}, \mathrm{cl} 857$ & [94] \\
\hline rhBMP-2 & PCYTEXP3-BMP-2 & $\mathrm{FB} ; 30$ to $42^{\circ} \mathrm{C}$ & $\begin{array}{l}20 \% \mathrm{TCP} \\
(8.5 \mathrm{~g} / \mathrm{L})\end{array}$ & $\lambda \mathrm{pL}, \mathrm{cl} 857$ & [94] \\
\hline hFGF-2 & plFGFB & $\mathrm{FB} ; 30$ to $42^{\circ} \mathrm{C}(6-8 \mathrm{~h})$ & $5-6 \mathrm{~g} / \mathrm{L}$ & $\lambda \mathrm{pRPL}$ cl857 & [95] \\
\hline hGH & pET21-hgh & $\begin{array}{l}\text { FB (complex media); } \\
30 \text { to } 42^{\circ} \mathrm{C}(30 \mathrm{~min}), \\
\text { reduction to } 37^{\circ} \mathrm{C}(4 \mathrm{~h})\end{array}$ & $\begin{array}{l}11 \% \mathrm{TCP} \\
(2.0 \mathrm{~g} / \mathrm{L})\end{array}$ & $\begin{array}{l}\text { pET21-hgh; pGP1-2 gene } 1 \\
\text { of T7 under } \lambda \mathrm{pL}\end{array}$ & {$[54]$} \\
\hline hGH & pET21-hgh & $\begin{array}{l}\text { FB (glycerol); } \\
30 \text { to } 42^{\circ} \mathrm{C}(30 \mathrm{~min}) \\
\text { reduction to } 37^{\circ} \mathrm{C}(4 \mathrm{~h})\end{array}$ & $\begin{array}{l}15 \% \mathrm{TCP} \\
(2.7 \mathrm{~g} / \mathrm{L})\end{array}$ & $\begin{array}{l}\text { pET21-hgh; pGP1-2 gene } 1 \\
\text { of T7 under } \lambda \mathrm{pL}\end{array}$ & {$[54]$} \\
\hline IFN- $\alpha 2 b$ & $\begin{array}{l}\text { pRSET-INF } \alpha \text { 2b; } \\
\text { pGP1-2 }\end{array}$ & $\begin{array}{l}\mathrm{BC}, \mathrm{SF} ; 30 \text { to } 42^{\circ} \mathrm{C} \\
(5,10 \text { and } 15 \mathrm{~min})\end{array}$ & $650 \mathrm{mg} / \mathrm{L}$ & $\lambda \mathrm{PL}, \mathrm{T} 7 \mathrm{RNA}$ pol, cl857 & {$[55]$} \\
\hline His-tag-hPPI & $\lambda$-PL-cl857 pUC & $\begin{array}{l}\mathrm{FB} ; 30 \text { to } 42^{\circ} \mathrm{C} \\
\text { heat rate } 0.4^{\circ} \mathrm{C} / \mathrm{min}\end{array}$ & $3.3 \mathrm{~g} / \mathrm{L}$ & $\lambda \mathrm{pL} / \mathrm{cl} 857$ & [15] \\
\hline His-tag- hPPI & $\lambda$-PL-cl857 pUC & $\begin{array}{l}\mathrm{FB} ; 30 \text { to } 42^{\circ} \mathrm{C} \\
\text { heat rate } 0.8^{\circ} \mathrm{C} / \mathrm{min}\end{array}$ & $2.2 \mathrm{~g} / \mathrm{L}$ & $\lambda \mathrm{pL} / \mathrm{cl} 857$ & [15] \\
\hline His tag- hPPI & $\lambda$-PL-cl857 pUC & $\begin{array}{l}\mathrm{FB} ; 30 \text { to } 42^{\circ} \mathrm{C} \\
\text { heat rate } 1.7^{\circ} \mathrm{C} / \mathrm{min}\end{array}$ & $1.8 \mathrm{~g} / \mathrm{L}$ & $\lambda \mathrm{pL} / \mathrm{cl} 857$ & {$[15]$} \\
\hline His tag- hPPI & $\lambda$-PL-cl857 pUC & $\begin{array}{l}\mathrm{FB} ; 30 \text { to } 42^{\circ} \mathrm{C} \\
\text { heat rate } 6^{\circ} \mathrm{C} / \mathrm{min}\end{array}$ & $1.9 \mathrm{~g} / \mathrm{L}$ & $\lambda \mathrm{pL} / \mathrm{cl} 857$ & [15] \\
\hline \multicolumn{6}{|c|}{ Recombinant protein localized in cytoplasm and supernatant } \\
\hline TK & PHETK2 & $\mathrm{BC}, \mathrm{SF} ; 30^{\circ} \mathrm{C}$ to $42^{\circ} \mathrm{C}(16 \mathrm{~h})$ & $\begin{array}{l}4 \% \text { soluble } \\
\text { TCP }\end{array}$ & $\lambda \mathrm{pL} / \mathrm{cl} 857$ & {$[50]$} \\
\hline TK & PHETK2 & $\mathrm{BC}, \mathrm{SF} ; 30^{\circ} \mathrm{C}$ to $42^{\circ} \mathrm{C}(16 \mathrm{~h})$ & $\begin{array}{l}4 \% \text { soluble } \\
\text { TCP }\end{array}$ & $\lambda \mathrm{pL} / \mathrm{cl} 857$ & {$[50]$} \\
\hline$\beta$-gal & pRA-A1lts-187Z & $\mathrm{BC}, \mathrm{SF} ; 30$ to $40^{\circ} \mathrm{C}(5 \mathrm{~h})$ & $\begin{array}{l}30 \% \mathrm{TCP} \\
(2.0 \mathrm{~g} / \mathrm{L})\end{array}$ & $\lambda \mathrm{pR}, \mathrm{cl} 857, \mathrm{PA} 1$ & [66] \\
\hline$\beta$-gal & pRA-A1lts-187Z & $\mathrm{BC} ; 30$ to $40^{\circ} \mathrm{C}$ & $\begin{array}{l}22 \% \mathrm{TCP} \\
(2.0 \mathrm{~g} / \mathrm{L})\end{array}$ & $\lambda \mathrm{pR}, \mathrm{cl} 857, \mathrm{PA} 1$ & {$[66]$} \\
\hline scFv & $\begin{array}{l}\text { pCMT2b-scFv; } \\
\text { pRcd1 }\end{array}$ & $\mathrm{BC}, \mathrm{SF} ; 30^{\circ} \mathrm{C}$ to $42^{\circ} \mathrm{C}(7 \mathrm{~h})$ & $37 \mathrm{mg} / \mathrm{L}$ & $\lambda \mathrm{pL} / \mathrm{cl} 857 ;$ Rcd IPR & [173] \\
\hline scFv & $\begin{array}{l}\text { pCMT2b-scFv; } \\
\text { pRcd1 }\end{array}$ & $\mathrm{FB} ; 30$ to $42^{\circ} \mathrm{C}(8 \mathrm{~h})$ & 160 mg/L & $\lambda \mathrm{pL} / \mathrm{cl} 857 ;$ Rcd IPR & [173] \\
\hline \multicolumn{6}{|c|}{ Recombinant protein localized in supernatant } \\
\hline Glucagon-SEAP & pBLGlu-2 & $\mathrm{BC}, \mathrm{SF} ; 30$ to $40^{\circ} \mathrm{C}$ & $\begin{array}{l}3.4 \mathrm{mg} / \mathrm{L} / \\
\text { OD600 }\end{array}$ & $\lambda \mathrm{pL} / \mathrm{cl} 857$ & [174] \\
\hline \multicolumn{6}{|c|}{ Recombinant protein localized in periplasm } \\
\hline $\begin{array}{l}\text { hGH-fusion to } \\
\text { DsbA }\end{array}$ & DsbA-hGH & $\mathrm{BC}, \mathrm{SF} ; 30$ to $42^{\circ} \mathrm{C}$ & $19 \%$ & $\lambda \mathrm{pL} / \mathrm{cl} 857$ & [125] \\
\hline $\mathrm{hGH}$ & $\begin{array}{l}\text { IPL-DsbA-hGH/ } \\
\text { pRK248clts }\end{array}$ & $\begin{array}{l}\mathrm{FB} ; 30 \text { to } 42^{\circ} \mathrm{C} \\
\text { heat rate } 6^{\circ} \mathrm{C} / \mathrm{min}\end{array}$ & $95 \mathrm{mg} / \mathrm{L}$ & $\lambda \mathrm{pL}-\mathrm{cl} 857$ & [142] \\
\hline
\end{tabular}

UVRA: UV resistant-isoform A; IHF: Integration host factor; IFN: interferon; GXP: Guanine-xanthine phosphoribosyltransferase; rpGH: recombinant porcine growth hormone; $\beta$-gal: $\beta$-galactosidase; SpA: staphylococcal protein; TNF: tumor necrosis factor; TRAIL: TNF-related apoptosis-inducing ligand; GFP: green fluorescent protein; Mut3sY: Shorter version of INF-g gene; rhBMP-2: recombinant human bone morphogenetic protein 2; hFGF-2: human fibroblast growth factor 2; hGH: human growth hormone; scFv: single chain variable fragment; hPPI: Human pre-proinsulin; TK: Thymidine kinase; SEAP alkaline phosphatase; $\lambda$ PL: bacteriophage lambda; IB: Inclusion bodies; TCP: total cell protein; SF: shake flasks; HCDC: high cell density cultures; BC: Batch culture; FB: Fed-batch culture; CC: Continuous culture.

the operator oR have allowed a tight repression even at temperatures as high as $39^{\circ} \mathrm{C}$, but still permit heterologous protein expression if temperature is increased between $39^{\circ} \mathrm{C}$ to $42^{\circ} \mathrm{C}$, allowing the use of bacteria, such Helicobacter, that are not able to grow at low temperatures [64].

To date, different promoter combinations controlled by cI857 have been reported, including cI857/pR $[65,66], \mathrm{cI} 857 / \mathrm{pR} / \mathrm{pRM}[63], \mathrm{cI} 857 / \mathrm{pL} / \mathrm{pR}$ in tandem $[10,63,67]$, and cI857/pL $[44,51,58,61,65]$ (See Table 1).
All such combinations appear to work equivalently and all of them share the same advantages, mentioned in the previous section, over other popular expression systems. In addition, the $\lambda \mathrm{pL} / \mathrm{pR}$-cI857 expression system shows other important advantages. One single copy of the cI857 gene produces enough repressor to completely inhibit the activity of $\mathrm{pL}$ or $\mathrm{pR}$ promoters, even if the promoters are present in multicopy plasmids [60]. The thermoinduced system can be used in virtually any $E$. coli strain and even in other Gram-negative bacteria like 
Erwinia and Serratia [68]. Furthermore, depending on the protein, bacterial strain, and culture conditions, the use of this expression system can yield as much as $30 \%$ of recombinant protein with respect to total cell protein [14].

Some attempts have exploited the strong $\lambda$ phage promoters and repressor but without employing temperature up-shifts for inducing recombinant protein production. In these cases a wild-type repressor is used instead of the thermolabile cI857 and induction is achieved by adding a chemical inducer such as mitomycin $\mathrm{C}$ or nalidixic acid. Such inducers drive heterologous protein expression by triggering the SOS response with the concomitant expression of Rec-A and thus the autocleavage of cI [69]. The use of $\mathrm{pL}$ promoter has also been proposed for constitutive expression, that is, without cI regulation [10]. This approach can work in the cases where the product is not toxic to the host cell or when plasmid instability (segregational or structural) is not a problem [4]. For example, $\beta$-galactosidase has been expressed as a reporter protein under the pL promoter [70]. Interestingly, in such a study it was shown that transcription from $\mathrm{pL}$ increased as temperature decreased and that mutations on $\mathrm{pL}$ enhanced its activity. Nonetheless, most of the $\mathrm{pL} / \mathrm{pR}$ expression systems developed use temperature induction to control heterologous protein expression.

Finally, other thermo-regulated expression systems have been developed during the last decade. For instance, thermolabile derivatives of the repressor protein Rro of the temperate Lactococcus lactis bacteriophage r1t have been obtained by comparative molecular modeling of the known 3D-structure of cI857 of $\lambda$ bacteriophage [71]. Another example is the thermo-regulated system conformed by the lacZop operator/ promotor that is efficiently repressed by the LacIts repressor at $30^{\circ} \mathrm{C}$ but total induction is achieved upon increasing the temperature to $42^{\circ} \mathrm{C}$ [72].

\section{Molecular responses after recombinant protein induction in the thermo-regulated expression system}

The temperature up-shift required to induce recombinant protein in the thermo-regulated expression system also causes a heat stress that activates the HSR (Figure 2). The HSR initiates with the simultaneous overexpression of orchestrated heat shock genes that protect the cell against thermo-denatured proteins and control homeostasis by increasing the thermotolerance [22,73-75]. In E. coli, most of the heat shock genes are transcribed effectively and specifically by the RNA polymerase holoenzyme bound to the alternative $\sigma 32$ (known also as $\sigma \mathrm{H}$ ) factor encoded by the rpoH gene [76-79]. The $\sigma 32$ is a master regulator that alters the expression of different genes, including transcription factors, and regulates the activity of the transcriptional apparatus itself as well as executes different roles in cell homeostasis [80]. The $\sigma 32$ regulon is formed by at least 120 genes organized in hierarchical clusters [80], including almost all coding sequences for proteins involved in folding and degradation, such as chaperones like ClpB, DnaK/J and GroEL/S, and proteases like Lon, ClpP, ClpC, HsIV (ClpY) HsIU, ClpQ, and FtsH $[81,82]$.

Temperature increases may cause nucleotide misincorporation and chromosome damage [80]. However, after $\sigma 32$ activation, members of the regulon can protect DNA and RNA, maintaining genomic integrity that is essential for cell survival at high temperatures [80]. Also, $\sigma 32$ regulates the expression of genes coding for proteins that sense glucose and different metallic ions in the extra-cytoplasmic environment, proteins implicated in the secretion and processing of envelope proteins, transporters, proteins related to energy generation, and enzymes necessary for synthesis of the phospholipids, lipopolysaccharides and peptidoglycans needed to maintain cell integrity $[80,83]$. Other regulon members transfer $\Delta 3$-isopentyl-PP to tRNA. Such tRNA modification stabilizes the codon-anticodon pairing and improves tRNA thermal resistance [84,85]. Furthermore, some chaperones participate in the correct function of small RNAs under high temperature [84].

The synthesis level of $\sigma 32$ is tightly regulated at low temperatures (below $32^{\circ} \mathrm{C}$ ) because its translation start site is occluded by inhibitory base pairing, however, when temperature increases, base pairing is destabilized and $\mathrm{rpoH}$ translation is enhanced [86,87]. At $30^{\circ} \mathrm{C}$, about 50 molecules of $\sigma 32$ per cell exist, whereas such amount increases about 17 -fold shortly (5 to $6 \mathrm{~min}$ ) after temperature is up-shifted to $42^{\circ} \mathrm{C}$, and decreases back to close to 250 molecules per cell $15 \mathrm{~min}$ after the temperature up-shift [88]. It has been shown that increasing the temperature to $37^{\circ} \mathrm{C}$ activates translation of $r p o H$ transcripts [88,89]. The activity of $\sigma 32$ is regulated by the so called "negative feedback loop" whereby chaperones such as DnaK/J and GroEL/S interact with $\sigma 32$, limiting its binding to RNA polymerase $[25,90,91]$ (Figure 2). When unfolded proteins are high relative to DnaK, this protein is titrated away from $\sigma 32$, triggering the HSR [25]. In contrast, when unfolded proteins are scarce, the DnaK/J and GroEL/S systems mediate the degradation of $\sigma 32[25,92]$. It has been suggested that DnaK can help degrade $\sigma 32$ by delivering it to the protease FtsH [92]. The current model for $\sigma 32$ regulation by DnaK chaperone has been referred to as the "unfolded protein titration" [73,93].

In addition to the cellular stress caused by an increase in temperature, protein overexpression by itself can also trigger stress responses. Recombinant protein produced 


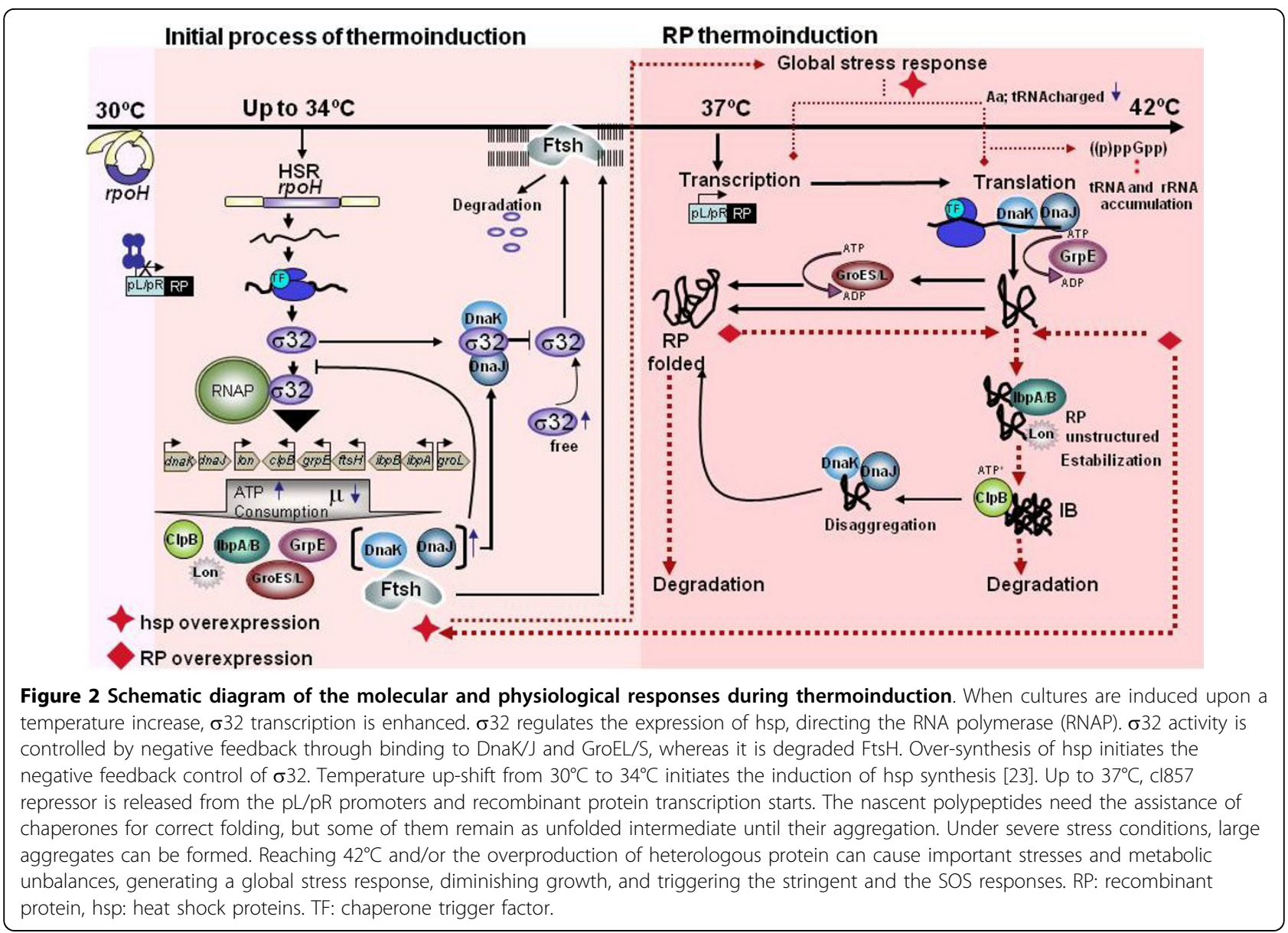

in the thermoinduced system can reach high concentrations and accumulate as inclusion bodies [7,15,94,95]. It is well known that overexpression and accumulation of unfolded recombinant proteins direct the response of genes involved in protein folding and degradation, which in turn are mainly controlled by $\sigma 32[17,96,97]$. The molecular responses observed include the upregulation of genes coding for heat shock proteins like DnaK, DnaJ, GroEL, GroES, ClpP, GrpE, DegP, IbpA, IbpB, and FtsH [17,97], as well as the genes ompT and ftsH, that code for proteases [17]. Moreover, the upregulation of genes involved in the SOS response, such as recA or lon, has also been reported [17,97]. It must be emphasized that activation of the molecular response to unfolded protein accumulation, as well as its duration, are dependent on the recombinant protein produced [17].

The molecular responses activated by heat or by unfolded protein accumulation have been studied extensively in separate contexts $[17,80,97-99]$. However, both responses converge in the activation of genes coding for chaperones and proteases. For instance, some genes (such as dnaK, dnaJ, ibpA, ibpB, lon, ftsH clpB, rpoS,
rpoH, omp T, and groEL) are rapidly upregulated within the first few minutes after heat shock or recombinant protein accumulation. In particular, dnaK, dnaJ, $\operatorname{clp} B$ and $i b p A$ increase several times during the initial $5 \mathrm{~min}$ $[15,17,80,88]$, while, the heterologous gene can increase as much as 150 times in 2 min [15]. Upregulation in general does not last for more than $40 \mathrm{~min}$. In contrast, the upregulation of lon, groEL, and $o m p T$, in response to accumulation of proteins like interleukin 2 (IL-2) or viral protein (VP5), can be maintained for more than 40 $\min$ [17].

Recently, transcriptomic and transcriptional approaches to analyze cultures with dual stress, consisting of heating above $37^{\circ} \mathrm{C}$ and inducing the accumulation of unfolded recombinant protein, have been performed [15,100]. Although, different protocols of heat and induction have been applied, both studies show that the dual stress activates genes like $r p o H$ and those associated with the heat shock response (dnaJ, dnaK, htpG, groEL, and groES) [15,100]. In a transcriptomic study by Harcum and Haddadin [100], the molecular responses in cultures heated at $50^{\circ} \mathrm{C}$, cultures induced chemically with IPTG, and cultures with dual 
stress were analyzed. They found that 163 genes from 1,881 studied, responded strongly in cultures with dual stress compared with cultures only heated or induced [100]. In particular, genes coding for RNA polymerase like rpoA/S and ribosome coding genes were downregulated, meaning that transcription and translation probably diminished. Moreover, genes associated to the pyruvate metabolism and glutamine biosynthesis were also downregulated. Interestingly, relA was downregulated [100]. Such gene codes for the protein guanosine 5'-triphosphate 3'diphosphate or guanosine 3',5'biphosphate (p)ppGpp synthetase I, which participates in the stringent response and its activation has been observed in response to protein production and accumulation [96]. In another study, a transcriptional analysis was performed to understand the cellular response to heat and overproduction of heterologous protein using the $\lambda \mathrm{pL}$ cI857 thermoinduced system [15]. In this case, temperature rather than chemical induction was employed. The results showed that heat shock proteins and proteases were upregulated several times, while the transcriptional levels of critical genes that control the heat-shock response ( $r p o H$ and $f t s H)$ had a relatively small increase (0.5 times) [15]. Furthermore, genes corresponding to the general stress response (rpoS), and those that code for RelA and SpoT (the proteins that control the stringent response) showed no significant changes.

\section{Physiological responses after induction in the thermo-regulated system}

One of the most notable changes in cell physiology upon induction by temperature up-shift is the decrease in specific growth rate, which is inversely related to recombinant protein synthesis rate [21]. Other changes include the increase in respiration [75], alteration of central carbon metabolism [75,101-103], modification of the lipid to protein ratio in the membranes $[26,80]$, ribosome destruction and DNA relaxation [104]. In particular, after increasing the temperature, the global protein synthesis increases by a factor of three, of which $20-25 \%$ correspond to hsp $[22,23,99,105,106]$. Such an increase generates an unstable environment that causes a critical metabolic burden that impacts growth rate and quantity of the protein produced $[99,106,107]$. The high rate of protein synthesis can also exhaust carbon skeletons and amino acids pools, mainly when minimal media is used $[108,109]$. Depletion of amino acids can result in large pools of deacylated tRNAs that upon attachment to ribosomes are recognized by RelA. This in turn triggers the immediate utilization of ATP and GTP or GDP by RelA to synthesize AMP and (p)ppGpp [110-112]. The (p)ppGpp alarmones activate the stringent stress response and promote a higher transcription of heatshock and other stress related genes such as those that code for proteases, which mainly degrade ribosomes $[19,113,114]$. During the stringent stress response, the synthesis of tRNA and rRNA, as well as the transcription of genes from the transcriptional-translational cell machinery are downregulated and thus the translation process is interrupted. This limits protein synthesis and cell growth capacities during recombinant protein production $[19,101,109,115]$.

Activation of heterologous protein overexpression and endogenous hsp, in response to thermoinduction, also increase the requirements for ATP by a factor of six $[75,116]$. Such a huge energy requirement is responsible for the observed increase in respiration, but is not enough to compensate the ATP demand for protein production, causing a transient drop in the cell energy charge $[75,103,117]$.

Under non-limiting glucose concentration, a better glucose assimilation is ensured by overexpression of genes coding for CAMP-catabolite regulation protein (CRP), and repression of genes coding for TCA enzymes. Also, high ATP requirement stimulates carbon flux through glycolysis followed by a decrease in growth rate [118]. For example, Wittmann et al. [103] reported that these entire metabolic changes impaired specific growth rate from $0.45 \mathrm{~h}^{-1}$ before induction, to only 0.17 $\mathrm{h}^{-1}$ after expression of the recombinant gene. Specifically, a temperature up-shift stimulated more than $20 \%$ of the glycolytic flux, whereas it decreased carbon fluxes through pentose phosphate and other biosynthetic pathways by around $57 \%$. In addition, fluxes around TCA cycle dropped by $35 \%$, but activation of the glyoxylate shunt was observed [103]. Moreover, after induction carbon flux through the pyruvate node is preferentially channeled through pyruvate oxidase, resulting in acetate accumulation $[103,119]$. Accumulation of organic acids has been observed during the induction phase as a means to compensate the unbalance at the pyruvate node due to the reduction in the flux through pyruvate dehydrogenase and the TCA cycle $[15,120]$.

When glucose is the limiting nutrient, carbon fluxes through the pentose phosphate pathway decrease upon temperature up-shift, whereas the fluxes through the Embden-Meyerhof-Parnas and TCA cycle increase, leading to a reduced flux through growth-associated pathways, such as the anabolic pathways [102]. Also, the anaplerotic reactions operate at low levels [102]. As the TCA activity is increased, $75 \%$ of the carbon source is converted into $\mathrm{CO}_{2}$ in induced cultures, compared to only $25 \%$ in cultures at $30^{\circ} \mathrm{C}[75,102,103]$. Consequently, carbon flux to acetate formation is absent during induced cultures under glucose limitation [103,121,122].

The metabolic and physiologic differences between induced and non-induced cultures impact glucose consumption and difficult the establishment of glucose 
feeding strategies during the post-induction phase. For instance, although the most common strategy to avoid overflow metabolism during induction is to reduce the pre-induction glucose-feeding rate, such an approach can result in carbon source limitation that reduces recombinant protein production [109,123], and activates ppGpp synthesis and the stringent stress response [101].

\section{Phenomena and variables that modulate the productivity in the thermo-regulated system}

Several phenomena and variables, that can modify or negatively affect recombinant protein productivity of the $\lambda \mathrm{pL} / \mathrm{pR}$-cI857 system, must be considered for optimal bioprocess performance. Among them, the most important include plasmid segregation, host strain, fermentation process, heating strategies (such as time and temperature of induction), cellular site where the recombinant protein is localized, and even the type of recombinant protein expressed $[55,124,125]$. The yields reported in the literature using the $\lambda \mathrm{pL}$ or $\mathrm{pR} / \mathrm{cI} 857$ thermoinduced system with different plasmids, under different culture and induction conditions, and expressing different recombinant protein are summarized in Table 1. Data have been grouped depending on the cellular location where the recombinant proteins accumulate.

\section{Plasmid segregation}

It has been shown that during prolonged periods of derepression of the $\lambda \mathrm{pL} / \mathrm{pR}$ promoters at temperatures up to $42^{\circ} \mathrm{C}$, the propagation of plasmid-free cells is favored $[16,126,127]$. Furthermore, the fraction of plasmid-free cells under derepression at 38 or $40^{\circ} \mathrm{C}$ has been reported to be lower than at $41^{\circ} \mathrm{C}$ or above $[16,127]$. For example, Sayadi et al. [128] detected that 12 and $48 \%$ of the cells had lost the plasmid after 250 generations at 37 and $42^{\circ} \mathrm{C}$, respectively. Nonetheless, some plasmids such as the thermoinduced pCY-TNF, show high segregational stability, as $70 \%$ of cells still harbor the plasmid after 200 generations in cultures at $42^{\circ} \mathrm{C}$ without selection pressure [10].

Plasmid instability during temperature up-shifts generally occurs in the $\mathrm{pL} / \mathrm{pR}$ promoter system $[52,129]$ because in dividing cells a partition mechanism necessary for stable plasmid inheritance has usually not been incorporated [128,130-132]. Examples of such mechanisms in other expression systems include bacterial plasmids encoding for the partitioning (par) loci, that ensure ordered plasmid segregation to daughter cells during division [133]. Moreover, plasmid maintenance and replication in host cells cause a metabolic load and the consumption of important cell resources [4,134]. Such a metabolic burden and energetic drain further increases upon induction of heterologous protein
$[4,135]$. It has been shown that the plasmid load causes a decrease in cell specific growth rate compared to plasmid-free cells [128,130-132].

Different operational conditions have been proposed to avoid plasmid segregation and extend the production phase after induction. For instance, plasmid copy number can be maintained by restricting the specific growth rate to low values $[136,137]$. This can be achieved through fed-batch protocols that result in high cell concentrations, such as in cultures with linearly or exponentially increasing rates of substrate addition before induction $[7,54,129]$. Another option, although rarely reported, is the use of two continuous cultures connected in series [128]. Cells are initially grown in a first chemostat at temperatures low enough to keep the promoter repressed and to conserve plasmid copy number. The effluent of the first chemostat is continuously fed to a second bioreactor, maintained at a higher temperature, where production of the recombinant protein occurs [128]. In such two-component systems high plasmid stability and high cell density cultures can be obtained in the first tank, whereas high productivity is achieved in the thermally induced bioreactor.

\section{Host strain}

Different $E$. coli strains present different heterologous gene expression capacities $[138,139]$, but few studies have attempted to determine the effect of host strain on recombinant protein production using plasmids that contain $\lambda$ elements. In one of such studies, different strains were transformed with plasmid $\lambda$ PL-DsbA (peptide signal of the periplasmic protein DsbA) containing the coding $h G H$ gene [125]. The highest hGH expression was obtained in W3110 and RB791 strains (19.6 and $16.2 \%$ of hGH with respect to total mass, respectively), whereas other strains produced several-fold less. One factor that may be important to consider for increasing the productivity is the use of protease-deficient strains [140]. For instance, Choi and Lee [141] reported that in a non-thermally induced culture, the protease-deficient BL21 E. coli was the most productive strain.

\section{Recombinant protein}

As described previously, the expression of a heterologous protein in the thermoinduced system triggers specific molecular and physiological responses in the host cell that can ultimately degrade the recombinant protein. However, the nature of each protein will be the main determinant of its stability [17]. Nonetheless, few reports have attempted to understand the effect of the particular recombinant protein being expressed by maintaining the same thermoinduced plasmid, host strain, and culture conditions. Even scarcer are the 
reports that dissect the particular effect of the recombinant protein on the molecular or physiological responses using the same expression system. An exception is the work by Soares et al. [142] who compared the expression of hGH and human prolactine (hPRL) using the same heat-inducible system. The hGH was successfully expressed and secreted into the E. coli periplasm, with yields above $1 \mathrm{mgL}^{-1} \mathrm{~A}_{600}{ }^{-1}$, whereas the yields for hPRL were about 50-times lower. Soares et al. [142] suggested that such an important difference in production between both proteins could be caused by differences in the thermal lability and/or proteolytic sensitivity of the heterologous proteins.

\section{Culture strategies}

Different culture strategies have been investigated to search for the optimum production scheme. Strategies such as the addition of complex-rich media with yeast extract, peptone or tryptone, alone or mixed [143], and protease inhibitors $[143,144]$ are commonly used. Other factors that can be controlled to improve the productivity are the induction temperature, duration of the induction, and the specific growth rate before or after induction [52,136]. Different culture modes, including batch, fed-batch and continuous, have been used to investigate the relationship between specific growth rate and protein production. Fed-batch processes have been particularly exploited for such purpose as these allow a tight control of the growth phase and can be temporally separated from the production phase, while maintaining plasmid stability and avoiding metabolic stress and production of toxic organic acids [52,94,136,137,145]. For example, by controlling the substrate feed rate during the growth phase and the specific growth rate during the production phase, Lim and Jung [52] attained high cell densities and a 23-fold increase in final interferon- $\gamma$ concentration in comparison with batch cultures. Likewise, Curless et al. [136] produced interferon- $\alpha$ by initially culturing the cells in a chemostat at $30^{\circ} \mathrm{C}$ under glucose limitation; after a steady state was achieved, a fed-batch mode was initiated and the temperature increased to $42^{\circ} \mathrm{C}$. Production of interferon- $\alpha$ increased 4-fold under the higher dilution rates tested, demonstrating the dependence of the pre-induction specific growth rate on productivity. As detailed previously, continuous cultures can also be employed with the thermoinduced expression system as long as the growth phase is separated from the production phase by means of two serially connected chemostats $[126,128]$.

\section{Heating strategies}

A variety of heating strategies have been developed to induce the expression of recombinant proteins. The main aims of such strategies have been to avoid the adverse effects of high temperature, such as decreased growth rate, damage to the host cells, decrease in viability and productivity, and plasmid instability $[15,54,55,95,115,129,137,142,146,147]$. Frequently, the temperature is increased from $28-32^{\circ} \mathrm{C}$ to $40-42^{\circ} \mathrm{C}$. In some cases, a few minutes after the temperature has been raised, it is decreased back to $38^{\circ} \mathrm{C}$ or $40^{\circ} \mathrm{C}$ (Table 1). For example, Tabandeh et al. [54] induced cultures at $42^{\circ} \mathrm{C}$ for 20 or $40 \mathrm{~min}$ and then decreased the temperature to $37^{\circ} \mathrm{C}$ for $4 \mathrm{~h}$. They reported that the recombinant protein was degraded when the induction phase at $42^{\circ} \mathrm{C}$ lasted $40 \mathrm{~min}$, whereas degradation was absent if temperature was decreased to $37^{\circ} \mathrm{C}$ within 20 minutes after induction.

The heating rate in a bioreactor is a relevant parameter because it can substantially differ from laboratory to large-scale, due to the fact that the ratio between the heat transfer area to volume decreases in an inverse function to the size of conventional stirred-tank bioreactors [148]. Nonetheless, such a parameter was overlooked until the recent work by Caspeta et al. [15], who established a scale-down approach to understand how heating rate differences, related to scale, affected recombinant protein production and cell performance. In such a study, heating rates of $6,1.7,0.8$, and $0.4^{\circ} \mathrm{C} / \mathrm{min}$, typical of $0.1,5,20$, and $100 \mathrm{~m}^{3}$ fermentors, respectively, were simulated in a laboratory scale bioreactor [15]. The maximum recombinant protein production and minimum accumulation of waste organic acid by-products was obtained during the slowest heating rates that emulated the largest scale fermentors [15]. Such results demonstrated that during faster heating rates, typical of laboratory conditions, the cells required more energy and experienced larger imbalances between glycolysis and the TCA cycle than during slower heating rates characteristic of large-scale vessels. The study also demonstrated that cells subjected to slow heating rates can better adapt to thermal stresses than those exposed to a faster temperature increase [15].

\section{Protein accumulation and recovery}

Recombinant proteins produced in the thermoinduced $\lambda \mathrm{pL} / \mathrm{pR}$-cI857 expression system can form aggregates in the cytoplasm, accumulate in soluble form either in the cytoplasm or the periplasmic space, or be secreted to the supernatant $[7,65,125,149]$. The site of protein accumulation depends on proper localization signals [125]. Production of recombinant proteins in the periplasmic space offers several advantages, such as decreased proteolytic activity compared to the cytoplasm, simpler purification protocols as fewer host proteins are present in the periplasm, and minimum amounts or even absence of undesirable isoforms and posttranscriptional modifications. Furthermore, the in vivo cleavage of the signal 
peptide provides authentic $\mathrm{N}$-terminus of the target protein (i.e., without an extra methionine). Another advantage is that correct formation of disulfide bonds can be facilitated because the periplasmic space provides a more oxidative environment than the cytoplasm $[14,125]$. Until now, few examples of soluble recombinant protein expression in periplasm using the $\lambda \mathrm{pL} / \mathrm{pR}$ cI857 system have been reported [125,142].

The increased temperature and high production rates alter protein folding, which in turn favors protein aggregation into inclusion bodies (IB) when using the $\lambda \mathrm{pL} /$ pR-cI857 system $[65,137,149,150]$. The factors that determine IB formation include the nature of the protein expressed (v. gr., protein sequence), growth and induction conditions, cytoplasmic reducing environment, kinetic competition between aggregation and folding, high local protein concentration, inappropriate interactions with in vivo folding chaperones, intermolecular disulfide crosslinking (although proteins lacking cysteines can still form inclusion bodies), medium composition, and bacterial strain [137,150-153]. Accumulation of the recombinant protein in IB has certain advantages, as it can be isolated and concentrated by a simple centrifugation step, reducing the downstream processing costs and facilitating the production of toxic proteins to cells [154-156]. However, a refolding step is then required to recover a biologically active protein, and refolding steps can be inefficient $[157,158]$.

Induction temperature, extracellular $\mathrm{pH}$, and the carbon source can either prevent or accelerate the formation of IB when employing the $\lambda \mathrm{pL} / \mathrm{pR}$-cI857 system [151]. IB typically contain around $20 \%$ to $85 \%$ of recombinant protein, whereas the remainder consists of a large set of host cellular proteins, particularly hsp such as chaperones and co-chaperones $[153,155,159,160]$, and other contaminants such as phospholipids, nucleic acids, and membrane proteins [152]. The chaperones DnaK and GroEL (together with their co-chaperones DnaJGrpE and GroES, respectively) have been identified as major components of IB produced in the thermoinduced system [155]. DnaK has been mostly localized on the surface of the IB, suggesting that this protein interacts with the IB after their formation [155]. In contrast, a significant fraction of GroEL has been observed within the IB, remaining trapped inside during the initial aggregation [155]. Interestingly, the absence of DnaK and GroEL in E. coli mutants significantly reduces bacterial growth [161]. Absence of DnaK results in larger IB, whereas a deficiency of GroEL reduces aggregation and favors soluble protein formation, with the concomitant production of smaller and numerous IB [155]. This has been explained as a combined consequence of a less efficient folding and impaired rescue (removal) of aggregates [161].
Interestingly, expression systems that are not based on heat induction have exploited phenomena present in the heat inducible expression system to improve various aspects of recombinant protein production. For instance, chaperones like DnaK/J or DnaK/J-GrpE/ClpB have been co-expressed to facilitate disaggregation and refolding of the recombinant protein of interest $[162,163]$. Likewise, the co-expression of GroEL/S with heterologous proteins such as zeta-crystallin [164] and carbamoylase [165] has significantly enhanced the yield of soluble proteins. Other examples include the co-expression of the DnaK-DnaJ-GrpE chaperones to increase the solubility of endostatin and human ORP150, or the overexpression of DnaJ to increase soluble transglutaminase content $[166,167]$. Overexpression of all such chaperons naturally occurs during thermoinduction of heterologous protein. Accordingly, the knowledge gained on the molecular and physiological events that occur during recombinant protein production by the $\lambda \mathrm{pL} / \mathrm{pR}$ cI857 system can be of great value to control and improve not only this expression system but others as well.

\section{Concluding remarks and future directions}

Many expression systems have been developed to increase recombinant protein production in E. coli, yet, the thermo-regulated system is particularly appropriate for large-scale protein production, because it is highly productive, can be finely regulated, is easily scalable, minimizes culture handling, and avoids the use of chemical inducers. However, there are still several unresolved problems, related to the molecular and physiological responses during induction of recombinant proteins, which cause an increased energy demand and metabolic burden that affect the final productivity and product quality. Other challenges, yet to be tackled, include the better exploitation of the beneficial effects of activation of $\sigma 32$ regulon members during thermoinduction, while avoiding the detrimental consequences. For instance, while overexpression of chaperones, proteases, and other proteins during thermoinduction can prevent protein aggregation and protect DNA and RNA that are necessary to maintain cellular integrity, it also represents an important drain in energy and precursors that are diverted from the production of the protein of interest. Important molecular responses occur quickly within the first two minutes after thermoinduction of heterologous protein and can last for more than 40 minutes. A better understanding of the kinetic behavior of such responses, for instance by transcriptional and proteomic approaches, will yield an integral knowledge of the phenomena that should allow the design of novel regulation and control strategies for improving recombinant protein production. 
With the aim of improving productivity, the recombinant proteins expressed under the thermoinduced system have been produced under different culture conditions, heating protocols, and recovery strategies, that can result in very different yields $[3,7,168]$. The development of novel induction strategies is an avenue of great potential. It is desirable to design protocols that avoid growth cessation, increase productivity and improve the purification of the recombinant protein, by modulating molecular responses such as the HSR. For instance, oscillatory temperature induction protocols could be exploited for such purpose. In this regard, there still remain questions related to the molecular and physiological responses, in particular, when non-conventional heating protocols are used. Finally, recovery and in vitro folding of heterologous proteins is a complex task due to the presence of various contaminant compounds. An interesting field that must be explored is the manipulation of the induction conditions to minimize the accumulation of impurities and favor the production of specific chaperones in order to improve product recovery and folding. Specifically a proteomic analysis of IB should help to identify contaminants that reduce yield or difficult the purification.

\section{Acknowledgements}

This work was partially financed by projects SEP-CONACYT $(82533,103393$, 104951), CONACYT-Fondo Salud (2007-c01-69911) (44126), PAPIIT-UNAM (IN228509, IN-224409, IN-223308).

\section{Author details}

'Departamento de Medicina Molecular y Bioprocesos, Instituto de Biotecnología, Universidad Nacional Autónoma de México. Avenida Universidad 2001, Cuernavaca Morelos, México. ${ }^{2}$ Probiomed S.A. de C.V. Planta Tenancingo, Cruce de Carreteras Acatzingo-Zumpahuacan SN, C.P. 52400 Tenancingo, Edo. de México, México. ${ }^{3}$ Unidad de Bioprocesos, Departamento de Inmunología, Instituto de Investigaciones Biomédicas, Universidad Nacional Autónoma de México, A.P. 70228, México, D.F., C.P. 04510, México.

\section{Authors' contributions}

NAVC, OTR, NOP and MATR suggested and defined the topic of this review article based on their industrial experience working with this particular expression system and their academic experience working with other expression systems. NAVC drafted the manuscript, OTR, MATR, NOP and LC revised it critically and amended the manuscript. All authors read and approved the final manuscript.

\section{Competing interests}

The authors declare that they have no competing interests.

Received: 27 January 2010 Accepted: 19 March 2010 Published: 19 March 2010

\section{References}

1. Hannig G, Makrides SC: Strategies for optimizing heterologous protein expression in Escherichia coli. Trends in Biotech 1998, 16:54-60.

2. Baneyx F: Recombinant protein expression in Escherichia coli. Curr Opin Biotechnol 1999, 10:411-421.

3. Panda AK: Bioprocessing of therapeutic proteins from the inclusion bodies of Escherichia coli. Adv Biochem Eng Biotechnol 2003, 85:43-93.
4. Palomares LA, Estrada-Mondaca S, Ramirez OT: Production of recombinant proteins: challenges and solutions. Methods Mol Biol 2004, 267:15-52.

5. Mergulhao FJ, Summers DK, Monteiro GA: Recombinant protein secretion in Escherichia coli. Biotechnol Adv 2005, 23(3):177-202.

6. Yin J, Li G, Ren X, Herrler G: Select what you need: A comparative evaluation of the advantages and limitations of frequently used expression systems for foreign genes. J Bacteriol 2007, 127:335-347.

7. Babu KR, Swaminathan S, Marten S, Khanna N, Rinas U: Production of interferon- $\alpha$ in high cell density cultures of recombinant Escherichia coli and its single step purification form refolded inclusion body proteins. App Microbiol Biotechnol 2000, 53:655-660.

8. Figge J, Wright C, Collins CJ, Robberts TM, Livingston DM: Stringent regulation of stably integrated chloramphenicol acetyl transferase genes by $E$. coli lac repressor in monkey cells. Cell 1988, 52:713-722.

9. Su TZ, Schweizer H, Oxender DL: A novel phosphate-regulated expression vector in Escherichia coli. Gene 1990, 90(1):129-33.

10. Menart V, Jevsevar S, Vilar M, Trobis A, Pavko A: Constitutive versus thermoinducible expression of heterologous proteins in Escherichia coli based on strong PR, PL promoters from phage lambda. Biotechnol Bioeng 2003, 83(2):181-190.

11. Ferenci T: Hungry bacteria - definition and properties of a nutritional state. Environ Microbiol 2001, 3:605-611.

12. Timms AR, Muriel W, Bridges BA: A UmuD, C-dependent pathway for spontaneous $\mathrm{G}: \mathrm{C}$ to $\mathrm{C}: \mathrm{G}$ transversions in stationary phase Escherichia coli. Mutat Res 1999, 435:77-80.

13. Jana S, Deb JK: Strategies for efficient production of heterologous proteins in Escherichia coli. Appl Microbiol Biotechnol 2005, 67(3):289-298.

14. Makrides SC: Strategies for achieving high-level expression of genes in Escherichia coli. Microbiol Rev 1996, 60(3):512-538.

15. Caspeta L, Flores N, Pérez NO, Bolívar F, Ramírez OT: The effect of heating rate on Escherichia coli metabolism, physiological stress, transcriptional response, and production of temperature-induced recombinant protein: a scale-down study. Biotechnol Bioeng 2009, 102(2):468-482.

16. Villaverde A, Benito A, Viaplana E, Cubarsi R: Fine regulation of cl857controlled gene expression in continuous culture of recombinant Escherichia coli by temperature. Appl Environ Microbiol 1993, 59(10):3485-3487.

17. Gill RT, Valdes JJ, Bentley WE: A comparative study of global stress gene regulation in response to overexpression of recombinant proteins in Escherichia coli. Metab Eng 2000, 2(3):178-189.

18. Hoffman F, Rinas U: Stress induced by recombinant protein production in Escherichia coli. Adv Biochem Eng/Biotechnol 2004, 89:73-92.

19. Dong H, Nilsson L, Kurland CG: Gratuitous overexpression of genes in Escherichia coli leads to growth inhibition and ribosome destruction. J Bacteriol 1995, 177(6):1497-504, Erratum in: J Bacteriol 1997, 179(6):2096.

20. George HA, Powell AL, Dahlgren ME, Herber WK, Maigetter RZ, Burgess BW, Stirdivant SM, Greasham RL: Physiological effects of TGF(alpha)-PE40 expression in recombinant Escherichia coli JM109. Biotechnol Bioeng 1992, 40(3):437-45.

21. Jensen EB, Carlsen S: Production of recombinant human growth hormone in Escherichia coli: Expression of different precursors and physiological effects of glucose, acetate, and salts. Biotechnol Bioeng 1990, 36(1):1-11

22. Hoffmann F, Rinas U: Kinetics of heat-shock response and inclusion body formation during temperature-induced production of basic fibroblast growth factor in high-cell-density cultures of recombinant Escherichia coli. Biotechnol Prog 2000, 16(6):1000-1007.

23. Yamamori T, Yura T: Temperature-induced synthesis of specific proteins in Escherichia coli: evidence for transcriptional control. J Bacteriol 1980, 142(3):843-851.

24. Grossman AD, Erickson JW, Gross CA: The htpR gene product of $E$. coli is a sigma factor for heat-shock promoters. Cell 1984, 38(2):383-390.

25. Guisbert E, Herman C, Lu CZ, Gross CA: A chaperone network controls the heat shock response in E. coli. Genes Dev 2004, 18(22):2812-2821.

26. Mejia R, Gómez-Eichelmann MC, Fernández MS: Fatty acid profile of Escherichia coli during the heat-shock response. Biochem Mol Biol Int 1999, 47(5):835-844.

27. Dodd IB, Shearwin KE, Egan JB: Revisited gene regulation in bacteriophage lambda. Curr Opin Genet Dev 2005, 15(2):145-152.

28. Lederberg J: The selection of genetic recombinations with bacterial growth inhibitors. J Bacterio/ 1950, 59(2):211-215. 
29. Dodd IB, Shearwin KE, Perkins AJ, Burr T, Hochschild A, Egan JB: Cooperativity in long-range gene regulation by the lambda $\mathrm{Cl}$ repressor. Genes Dev 2004, 18(3):344-354.

30. Maniatis T, Patshne M: Multiple repressor binding at the operators in bacteriophage lambda. Proc Natl Acad Sci 1973, 70:1531-1535.

31. Ptashne M, Jeffrey A, Johnson AD, Maurer R, Meyer BJ, Pabo CO, Roberts TM, Sauer RT: How the lambda repressor and cro work. Cell 1980, 19(1):1-11.

32. Johnson AD, Meyer BJ, Ptashne M: Interactions between DNA-bound repressors govern regulation by the lambda phage repressor. Proc Natl Acad Sci USA 1979, 76:5061-5065.

33. Stayrook S, Jaru-Ampornpan P, Ni J, Hochschild A, Lewis M: Crystal structure of the lambda repressor and a model for pairwise cooperative operator binding. Nature 2008, 452(7190):1022-1025.

34. Dodd IB, Perkins AJ, Tsemitsidis D, Egan JB: Octamerization of lambda Cl repressor is needed for effective repression of $P(R M)$ and efficient switching from lysogeny. Genes Dev 2001, 15(22):3013-3022.

35. Meyer BJ, Maurer R, Ptashne M: Gene regulation at the right operator (OR) of bacteriophage lambda. II. OR1, OR2, and OR3: their roles in mediating the effects of repressor and cro. J Mol Biol 1980, 139(2):163-194.

36. Maurer R, Meyer B, Ptashne M: Gene regulation at the right operator (OR) bacteriophage lambda. I. OR3 and autogenous negative control by repressor. J Mol Biol 1980, 139(2):147-161.

37. Darling PJ, Holt JM, Ackers GK: Coupled energetics of lambda cro repressor self-assembly and site-specific DNA operator binding I: analysis of cro dimerization from nanomolar to micromolar concentrations. Biochem 2000, 39(37):11500-11507.

38. Ptashne M: A Genetic Switch: Phage I and Higher Organisms. Cambridge Massachusetts, 21992.

39. Jiang SC, Paul JH: Significance of Lysogeny in the Marine Environment: Studies with Isolates and a Model of Lysogenic Phage Production. Microb Ecol 1998, 35(3):235-243.

40. Oakey HJ, Owens L: A new bacteriophage, VHML, isolated from a toxinproducing strain of Vibrio harveyi in tropical Australia. J Appl Microbiol 2000, 89(4):702-709.

41. Liveris D, Mulay $V$, Schwartz I: Functional properties of Borrelia burgdorferi recA. J Bacteriol 2004, 186(8):2275-2280.

42. Lieb M: Studies of heat-inducible lambda bacteriophage, I. Order of genetics sites and properties of mutant prophages. J Mol Biol 1996, 16:149-163.

43. Lieb M: A fine structure map of spontaneous and induced mutations in the lambda repressor gene, including insertions of IS elements. Mol Gen Genet 1981, 184(3):364-371.

44. Yoakum GH, Yeung AT, Mattes WB, Grossman L: Amplification of the uvrA gene product of Escherichia coli to $7 \%$ of cellular protein by linkage to the pL promoter of pKC30. Proc Natl Acad Sci USA 1982, 79:1766-1770.

45. Lohman TM, Green JM, Beyer RS: Large-scale overproduction and rapid purification of the Escherichia coli ssb gene product. Expression of the ssb gene under lambda pL control. Biochem 1986, 25:21-25.

46. Bognar AL, Osborne C, Shane B, Singer SC, Ferone R: Folylpoly-gammaglutamate synthetase-dihydrofolate synthetase. Cloning and high expression of the Escherichia coli folC gene and purification and properties of the gene product. J Biol Chem 1985, 260:5625-5630.

47. Cheng SC, Kim R, King K, Kim SH, Modrich P: Isolation of gram quantities of EcoRI restriction and modification enzymes from an overproducing strain. J Biol Chem 1984, 259:11571-11575.

48. Pham TT, Coleman JE: Cloning, expression, and purification of gene 3 endonuclease from bacteriophage T7. Biochem 1985, 24:5672-5677.

49. Roulet $\mathrm{R}$, Allet $\mathrm{B}$, Chandler M: Cloning and expression of the phage Mu A gene. Gene 1984, 28:65-72.

50. Waldman AS, Haeusslein E, Milman G: Purification and characterization of herpes simplex virus (type 1) thimidine kinase produced in Escherichia coli by a high efficiency expression plasmid utilizing a lambda $\mathrm{pL}$ promoter and cl857 temperature-sensitive repressor. J Biol Chem 1983, 10:11571-11575.

51. Remaut $E$, Tsao $H$, Fiers W: Inducible high level synthesis of mature human fibroblast interferon in Escherichia coli. Nucleic Acids Res 1983, 11:4677-4688.
52. Lim HK, Jung KH: Improvement of heterologous productivity by controlling postinductive specific growth rate in recombinant Escherichia coli under control of the PL promoter. Biotechnol Prog 1998, 14:548-553.

53. Schmidt M, Babu KR, Khanna N, Marten S, Rinas U: Temperature-induced production of recombinant human insulin in high-cell density cultures of recombinant Escherichia coli. J Biotechnol 1999, 68(1):71-83.

54. Tabandeh F, Shojaosadati SA, Zomorodipour A, Khodabandeh M, Sanati $\mathrm{MH}$, Yakhchali B: Heat induced production of human growth hormone by high cell density cultivation of recombinant Escherichia coli. Biotechnol Lett 2004, 26:245-250.

55. Srivastava P, Bhattacharaya P, Pandey G, Mukherjee KJ: Overexpression and purification of recombinant human interferon alpha2b in Escherichia coli. Protein Expr Purif 2005, 41:313-322.

56. Backman K, Ptashne M, Gilbert W: Construction of plasmids carrying the $\mathrm{cl}$ gene of bacteriophage $\lambda$. Proc Natl Acad Sci USA 1976, 73:4174-4178.

57. Bernard HU, Remaut E, Hershfield MV, Das HK, Helinski DR, Yanofsky C, Franklin N: Construction of plasmid cloning vehicles that promote gene expression from the bacteriophage lambda pL promoter. Gene 1979, 5(1):59-76.

58. Liu SW, Milman G: Purification and characterization of Escherichia coli Guanine-xanthine phosphoribosyltransferase produced by a high efficiency expression plasmid utilizing a $\lambda \mathrm{pL}$ promoter and $\mathrm{cl} 857$ temperature-sensitive repressor. J Biol Chem 1983, 258:7469-7475.

59. Remaut $E$, Tsao $H$, Fiers W: Improved plasmid vectors with a thermoinducible expression and temperature-regulated runaway replication. Gene 1983, 22:103-113.

60. Remaut E, Stranssens P, Fiers W: Plasmid vectors for high-efficiency expression controlled by the $\mathrm{pL}$ promoter of coli phage lambda. Gene 1981, 15:81-93.

61. Remaut E, Stanssens P, Fiers W: Inducible high level synthesis of mature human fibroblast interferon in Escherichia coli. Nucleic Acids Res 1983, 11(14):4677-4688.

62. Crowl R, Seamans C, Lomedico P, McAndrew S: Versatile expression vector for high-level synthesis of cloned gene products in Escherichia coli. Gene 1985, 38(1-3):31-38.

63. Elvin CM, Thompson PR, Argall ME, Hendry P, Stamford PJ, Lilley PE, Dixon NE: Modified bacteriophage lambda promoter vectors for overproduction of proteins in Escherichia coli. Gene 1990, 87:123-126.

64. Jechlinger W, Glocker J, Haidinger W, Matis A, Szostak MP, Lubitz W: Modulation of gene expression by promoter mutants of the lambdacl857/pRM/pR system. J Biotechnol 2005, 116(1):11-20.

65. Strandberg L, Andersson L, Enfors SO: The use of fed batch cultivation for achieving high cell densities in the production of a recombinant protein in Escherichia coli. FEMS Microbiol Rev 1994, 14(1):53-56.

66. Chao YP, Wen CS, Wang JY: A facile and efficient method to achieve LacZ overproduction by the expression vector carrying the thermo-regulated promoter and plasmid copy number. Biotechnol Prog 2004, 20(2):420-425.

67. Chao YP, Law W, Chen PT, Hung WB: High production of heterologous proteins in Escherichia coli using the thermo-regulated T7 expression system. App Microbiol Biotechnol 2002, 58(4):446-453.

68. Leemans R, Remaut E, Fiers W: A broad-host-range expression vector based on the $\mathrm{pL}$ promoter of coliphage $\lambda$ : regulated synthesis of human interleukin 2 in Erwinia and Serratia species. J Bacteriol 1987, 169:1899-1904.

69. Mott JE, Grant RA, Ho YS, Platt T: Maximizing gene expression from plasmid vectors containing the lambda pL promoter: strategies for overproducing transcription termination factor rho. Proc Natl Acad Sci USA 1985, 82(1):88-92.

70. Giladi H, Goldenberg D, Koby S, Oppenheim AB: Enhanced activity of the bacteriophage lambda PL promoter at low temperature. Proc Natl Acad Sci USA 1995, 92(6):2184-2188.

71. Nauta A, Burg van den B, Karsens H, Venema G, Kok J: Design of thermolabile bacteriophage repressor mutants by comparative molecular modeling. Nat Biotechnol 1997, 15(10):980-983.

72. Hasan N, Szybalski W: Construction of laclts and laclats expression plasmids and evaluation of the thermosensitive lac repressor. Gene 1995, 163(1):35-40.

73. Bukau B: Regulation of the Escherichia coli heat-shock response. Mol Microbiol 1993, 9:671-680 
74. Arsène F, Tomoyasu T, Bukau B: The heat shock response of Escherichia coli. Int J Food Microbiol 2000, 55(1-3):3-9.

75. Hoffmann F, Weber J, Rinas U: Metabolic adaptation of Escherichia coli during temperature-induced recombinant protein production: 1 . Readjustment of metabolic enzyme synthesis. Biotechnol Bioeng 2002, 80(3):313-319.

76. Grossman AD, Straus DB, Walter WA, Gross CA: Sigma 32 synthesis can regulate the synthesis of heat shock proteins in Escherichia coli. Genes Dev 1987, 1:179-184.

77. Bloom M, Skelly S, VanBogelen R, Neidhardt F, Brot N, Weissbach H: In vitro effect of the Escherichia coli heat shock regulatory protein on expression of heat shock genes. J Bacteriol 1986, 166(2):380-384.

78. Morita MT, Kanemori M, Yanagi H, Yura T: Dynamic interplay between antagonistic pathways controlling the sigma 32 level in Escherichia coli. Proc Natl Acad Sci USA 2000, 97(11):5860-5865.

79. Dartigalongue C, Missiakas D, Raina S: Characterization of the Escherichia coli sigma E regulon. J Biol Chem 2001, 276(24):20866-20875.

80. Nonaka G, Blankschien M, Herman C, Gross CA, Rhodius VA: Regulon and promoter analysis of the $E$. coli heat-shock factor, sigma32, reveals a multifaceted cellular response to heat stress. Genes Dev 2006, 20(13):1776-1789.

81. Maurizi MR, Clark WP, Kim SH, Gottesman S: Clp P represents a unique family of serine proteases. J Biol Chem 1990, 265(21):12546-12552.

82. Chuang SE, Blattner FR: Characterization of twenty-six new heat shock genes of Escherichia coli. J Bacteriol 1993, 175(16):5242-5252.

83. Shin D, Lim S, Seok YJ, Ryu S: Heat shock RNA polymerase (E sigma(32)) is involved in the transcription of mlc and crucial for induction of the Mlc regulon by glucose in Escherichia coli. J Biol Chem 2001, 276(28):25871-25875.

84. Tsui HC, Feng G, Winkler ME: Transcription of the mutL repair, miaA tRNA modification, $h f q$ pleiotropic regulator, and $h f l A$ region protease genes of Escherichia coli K-12 from clustered Esigma32-specific promoters during heat shock. J Bacteriol 1996, 178:5719-5731.

85. Bjork G, Hagervall T: Transfer RNA Modification. I In Escherichia coli and Salmonella typhimurium. Cellular and Molecular Biology Washington, D.C.: American Society of MicrobiologyNeidhardt FC, Curtiss R III, Ingraham $\mathrm{JL}$, Lin ECC, Low KB, Magasanik B 2005, Module 4.6.2.

86. Morita MT, Tanaka Y, Kodama TS, Kyogoku Y, Yanagi H, Yura T: Translational induction of heat shock transcription factor sigma32: evidence for a built-in RNA thermosensor. Genes Dev 1999, 13(6):655-665.

87. Nagai $H$, Yuzawa $H$, Yura $T$ : Regulation of the heat shock response in $E$ coli: involvement of positive and negative cis-acting elements in translation control of sigma 32 synthesis. Biochimie 1991, 73(12):1473-1479.

88. Straus DB, Walter WA, Gross CA: The heat shock response of $E$. coli is regulated by changes in the concentration of sigma 32. Nature 1987, 329(6137):348-351

89. Tilly K, Erickson J, Sharma S, Georgopoulos C: Heat shock regulatory gene $\mathrm{rpoH}$ mRNA level increases after heat shock in Escherichia coli. J Bacteriol 1986, 168(3):1155-1158.

90. Tilly K, McKittrick N, Zylicz M, Georgopoulos C: The dnaK protein modulates the heat-shock response of Escherichia coli. Cell 1983, 34(2):641-646

91. Tilly K, Spence J, Georgopoulos C: Modulation of stability of the Escherichia coli heat shock regulatory factor sigma. J Bacteriol 1989, 171(3):1585-1589.

92. Herman C, Thevenet D, D'Ari R, Bouloc P: Degradation of $\sigma 32$, the heat shock regulator in Escherichia coli is governed by HflB. Proc Natl Acad Sci USA 1995, 92(8):3516-3520.

93. Craig EA, Gross CA: Is hsp70 the cellular thermometer. Trends Biochem Sci 1991, 16:135-140.

94. Vallejo LF, Brokelmann M, Marten S, Trappe S, Cabrera-Crespo J, Hoffmann A, Gross G, Weich HA, Rinas U: Renaturation and purification of bone morphogenetic protein-2 produced as inclusion bodies in highcell-density cultures of recombinant Escherichia coli. J Biotechnol 2002, 94(2):185-194.

95. Rinas U, Hoffmann F: Selective leakage of host-cell proteins during highcell-density cultivation of recombinant and non-recombinant Escherichia coli. Biotechnol Prog 2004, 20(3):679-687.

96. Jürgen B, Lin HY, Riemschneider S, Scharf C, Neubauer P, Schmid R, Hecker $M$, Schweder T: Monitoring of genes that respond to overproduction of an insoluble recombinant protein in Escherichia coli glucose-limited fed-batch fermentations. Biotechnol Bioeng 2000, 70(2):217-224

97. Smith HE: The transcriptional response of Escherichia coli to recombinant protein insolubility. J Struct Funct Genomics 2007, 8(1):27-35.

98. Rosen R, Ron EZ: Proteome analysis in the study of the bacterial heatshock response. Mass Spectrom Rev 2002, 21(4):244-265.

99. Zhao K, Liu M, Burgess RR: The global transcripcional response of Escherichia coli to induced sigma 32 protein involves sigma 32 regulon activation followed by inactivation and degradation of sigma 32 in vivo. J Biol Chem 2005, 280(18):17758-17768.

100. Harcum SW, Haddadin FT: Global transcriptome response of recombinant Escherichia coli to heat-shock and dual heat-shock recombinant protein induction. J Ind Microbiol Biotechnol 2006, 33(10):801-814.

101. Cashel M, Gentry D, Hernandez V, Vinella D: The stringent response. In Escherichia coli and Salmonella typhimurium. Cellular and Molecular Biology 1996, 1458-1496.

102. Weber J, Hoffmann F, Rinas U: Metabolic adaptation of Escherichia coli during temperature-induced recombinant protein production: 2. Redirection of metabolic fluxes. Biotechnol Bioeng 2002, 80(3):320-330.

103. Wittmann C, Weber J, Betiku E, Krömer J, Böhm D, Rinas U: Response of fluxome and metabolome to temperature-induced recombinant protein synthesis in Escherichia coli. J Biotechnol 2007, 132:375-384.

104. López-García P, Forterre P: DNA topology and the thermal stress response, a tale from mesophiles and hyperthermophiles. Bioessays 2000, 22(8):738-746.

105. Hoffmann F, Rinas U: On-line estimation of the metabolic burden resulting from the synthesis of plasmid-encoded and heat-shock proteins by monitoring respiratory energy generation. Biotechnol Bioeng 2001, 76(4):333-340.

106. Wegrzyn $G$, Wegrzyn A: Stress responses and replication of plasmids in bacterial cells. Microb Cell Fact 2002, 1(1):2.

107. Gross CA: Function and regulation of the heat shock proteins. In Escherichia coli and Salmonella typhimurium. Cellular and Molecular Biology Washington, D.C.: American Society of MicrobiologyNeidhardt FC, Curtiss R III, Ingraham JL, Lin ECC, Low KB, Magasanik B 1996, 1382-1399.

108. Lemaux PG, Herendeen SL, Bloch PL, Neidhardt FC: Transient rates of synthesis of individual polypeptides in $E$. coli following temperature shifts. Cell 1978, 13:427-434.

109. Sandén AM, Prytz I, Tubulekas I, Förberg C, Le H, Hektor A, Neubauer P, Pragai Z, Harwood C, Ward A, Picon A, De Mattos JT, Postma P, Farewell A, Nyström T, Reeh S, Pedersen S, Larsson G: Limiting factors in Escherichia coli fed-batch production of recombinant proteins. Biotechnol Bioeng 2003, 81(2):158-166.

110. Haseltine WA, Block R, Gilbert W, Weber K: MSI and MSII made on ribosome in idling step of protein synthesis. Nature 1972, 238(5364):381-384.

111. Sy J, Lipmann F: Identification of the synthesis of guanosine tetraphosphate (MS I) as insertion of a pyrophosphoryl group into the 3'-position in guanosine 5'-diphosphate. Proc Natl Acad Sci USA 1973, 70:306-309.

112. Wendrich TM, Blaha G, Wilson DN, Marahiel MA, Nierhaus KH: Dissection of the mechanism for the stringent factor RelA. Mol Cell 2002, 10:779-788.

113. Jishage $M$, Kvint $K$, Shingler $V$, Nyström $T$ : Regulation of sigma factor competition by the alarmone ppGpp. Genes Dev 2002, 16(10):1260-1270.

114. Artsimovitch I, Patlan V, Sekine S, Vassylyeva MN, Hosaka T, Ochi K, Yokoyama S, Vassylyev DG: Structural basis for transcription regulation by alarmone ppGpp. Cell 2004, 117(3):299-310.

115. Rinas U: Synthesis rate of cellular proteins involved in translation and protein folding are strongly altered in response to overproduction of basic fibroblast growth factor by recombinant Escherichia coli. Biotechnol Prog 1996, 12:197-200.

116. da Silva NA, Bailey JE: Theoretical growth yield estimates for recombinant cells. Biotechnol Bioeng 1986, 28(5):741-746.

117. Ko YF, Bentley WE, Weigand WA: The effect of cellular energetics on foreign protein production. Appl Biochem Biotechnol 1995, 50(2):45-59.

118. Koebmann BJ, Westerhoff HV, Snoep JL, Nilsson D, Jensen PR: The glycolytic flux in Escherichia coli is controlled by the demand for ATP. $J$ Bacteriol 2002, 84(14):3909-3916.

119. Moreau PL: Diversion of the metabolic flux from pyruvate dehydrogenase to pyruvate oxidase decreases oxidative stress during 
glucose metabolism in nongrowing Escherichia coli cells incubated under aerobic, phosphate starvation conditions. J Bacterio/ 2004, 186(21):7364-7368.

120. Luli GW, Strohl WR: Comparison of growth, acetate production, and acetate inhibition of Escherichia coli strains in batch and fed-batch fermentations. Appl Environ Microbiol 1990, 56(4):1004-1011.

121. Farmer WR, Liao JC: Reduction of aerobic acetate production by Escherichia coli. Appl Environ Microbiol 1997, 63(8):3205-3210.

122. Phue JN, Noronha SB, Hattacharyya R, Wolfe AJ, Shiloach J: Glucose metabolism at high density growth of E. coli B and E. coli K: differences in metabolic pathways are responsible for efficient glucose utilization in E. coli B as determined by microarrays and Northern blot analyses. Biotechnol Bioeng 2005, 90(7):805-20, Erratum in: Biotechnol Bioeng 2005, 91 (5):649.

123. Wong HH, Kim YC, Lee SY, Chang HN: Effect of post-induction nutrient feeding strategies on the production of bioadhesive protein in Escherichia coli. Biotechnol Bioeng 1998, 60(3):271-276.

124. Diaz-Ricci JC, Hernandez ME: Plasmid effects on Escherichia coli metabolism. Crit Rev Biotechnol 2000, 20:79-108.

125. Soares $C R$, Gomide Fl, Ueda EK, Bartolini P: Periplasmic expression of human growth hormone via plasmid vectors containing the lambda PL promoter: use of HPLC for product quantification. Prot eng 2003, 16(12):1131-1138.

126. Siegel R, Ryu DD: Kinetic study of instability of recombinant plasmid pPLc23trpAl in E. coli using two-stage continuous culture system. Biotechnol Bioeng 1985, 27(1):28-33.

127. Hortacsu A, Ryu DD: Optimal temperature control policy for a two-stage recombinant fermentation process. Biotechnol Prog 1990, 6(6):403-407.

128. Sayadi S, Nasri M, Berry F, Barbotin JN, Thomas D: Effect of temperature on the stability of plasmid pTG201 and productivity of xylE gene product in recombinant Escherichia coli: development of a two-stage chemostat with free and immobilized cells. J Gen Microbiol 1987, 133(7):1901-1908.

129. Lee IY, Seo DJ, Lee SB: Influence of plasmid properties on fermentation parameters of recombinant Escherichia coli. J Microbiol Biotechnol 1992, 2:35-40.

130. Meacock PA, Cohen SN: Partitioning of bacterial plasmids during cell division: a cis-acting locus that accomplishes stable plasmid inheritance. Cell 1980, 20(2):529-542.

131. Nordström K, Molin S, Aagaard-Hansen H: Partitioning of plasmid R1 in Escherichia coli. II. Incompatibility properties of the partitioning system. Plasmid 1980, 4(3):332-339.

132. Nordström K, Molin S, Aagaard-Hansen H: Partitioning of plasmid R1 in Escherichia coli. I. Kinetics of loss of plasmid derivatives deleted of the par region. Plasmid 1980, 4(2):215-227.

133. Ebersbach G, Gerdes K: Plasmid segregation mechanisms. Annu Rev Genet 2005, 39:453-479.

134. Cunningham DS, Koepsel RR, Ataai MM, Domach MM: Factors affecting plasmid production in Escherichia coli from a resource allocation standpoint. Microb Cell Fact 2009, 22:8-27.

135. Bentley WE, Quiroga OE: Investigation of subpopulation heterogeneity and plasmid stability in recombinant Escherichia coli via a simple segregated model. Biotechnol Bioeng 1993, 42(2):222-234.

136. Curless C, Pope J, Tsai L: Effect of pre-induction specific growth rate on recombinant alpha-consensus interferon synthesis in Escherichia coli. Biotechnol Prog 1990, 6(2):149-152.

137. Aucoin MG, McMurray-Beaulieu V, Poulin F, Boivin EB, Chen J, Ardelean FM, Cloutier M, Choi YJ, Miguez CB, Jolicoeur M: Identifying conditions for inducible protein production in E. coli: combining a fed-batch and multiple induction approach. Microb Cell Fact 2006, 5:27.

138. Kaytes PS, Theriault NY, Poorman RA, Murakami K, Tomich C-SC: High-level expression of human renin in Escherichia coli. J Biotechnol 1986, 4(4):205-218.

139. Bower DM, Prather KL: Engineering of bacterial strains and vectors for the production of plasmid DNA. Appl Microbiol Biotechnol 2009, 82(5):805-813.

140. Baneyx F, Georgiou G: Construction and characterization of Escherichia coli strains deficient in multiple secreted proteases: protease III degrades high-molecular-weight substrates in vivo. J Bacteriol 1991, 173(8):2696-2703.
141. Choi JW, Lee SY: Enhanced expression of bovine growth hormone gene by different culture conditions in Escherichia coli. Biotechnol Lett 1997, 19(8):735-739.

142. Soares CR, Ueda EK, Oliveira TL, Gomide Fl, Heller SR, Bartolini P: Distinct human prolactin (hPRL) and growth hormone (hGH) behavior under bacteriophage lambda PL promoter control: temperature plays a major role in protein yields. J Biotechnol 2008, 133(1):27-35.

143. Harrison JS, Keshavarz-Moore E, Dunnill P, Berry MJ, Fellinger A, Frenken L: Factors affecting the fermentative production of a lysozyme-binding antibody fragment in Escherichia coli. Biotechnol Bioeng 1997, 53(6):611-622.

144. Yoon SK, Kang WK, Park TH: Fed-batch operation of recombinant Escherichia coli containing trp promoter with controlled specific growth rate. Biotechnol Bioeng 1994, 43(10):995-999.

145. Seeger A, Schneppe B, McCarthy JEG, Deckwer WD, Rinas U: Comparison of temperature- and isopropyl- $\beta$-d-thiogalacto-pyranoside-induced synthesis of basic fibroblast growth factor in high-cell-density cultures of recombinant Escherichia coli. Enzyme Microb Technol 1995, 17(10):947-953.

146. Kuriki Y: Response to temperature shifts of expression of the amp gene on pBR322 in Escherichia coli K-12. J Bacteriol 1987, 169(5):2294-2297.

147. Ryan W, Collier P, Loredo L, Pope J, Sachdev R: Growth kinetics of Escherichia coli and expression of a recombinant protein and its isoforms under heat shock conditions. Biotechnol Prog 1996, 12:596-601.

148. Nielsen J, Villadsen J, Gunnar L: Bioreaction engineering principles. New York: LidenKluwer Academic/Plenum Publishers, 2 2003, 477-517.

149. Kane JF, Hartley DL: Formation of recombinant protein inclusion bodies in Escherichia coli. Trends Biotechnol 1988, 6:95-101.

150. Fink AL: Protein aggregation: folding aggregates, inclusion bodies and amyloid. Fold Des 1998, 3(1):R9-23.

151. Strandberg L, Enfors SO: Factors influencing inclusion body formation in the production of a fused protein in Escherichia coli. App Environ Microbiol 1991, 57(6):1669-1674.

152. Valax P, Georgiou G: Molecular characterization of b-lactamase inclusion bodies produced in Escherichia coli. 1. Composition. Biotechnol Prog 1993, 9:539-547.

153. Rinas U, Bailey JE: Protein compositional analysis of inclusion bodies produced in recombinant Escherichia coli. Appl Microbiol Biotechnol 1992, 37:609-614.

154. Lee SY: High cell-density culture of Escherichia coli. Trends Biotechnol 1996, 14:98-105.

155. Carrió MM, Villaverde A: Localization of chaperones DnaK and GroEL in bacterial inclusion bodies. J Bacteriol 2005, 187(10):3599-3601.

156. Lee GH, Cooney D, Middelberg AP, Choe WS: The economics of inclusion body processing. Bioprocess Biosyst Eng 2006, 29:73-90.

157. De Bernardez Clark E: Refolding of recombinant proteins. Curr Opin Biotechnol 1998, 9:157-163.

158. Misawa S, Kumagai I: Refolding of therapeutic proteins produced in Escherichia coli as inclusion bodies. Biopolymers 1999, 51:297-307.

159. Rinas U, Bailey JE: Overexpression of bacterial hemoglobin causes incorporation of pre-lactamase into cytoplasmic inclusion bodies. Appl Microbiol Biotechnol 1993, 59:561-566.

160. Rinas U, Boone TC, Bailey JE: Characterization of inclusion bodies in recombinant Escherichia coli producing high levels of porcine somatotropin. J Biotechnol 1993, 28:313-320.

161. Gonzaléz-Montalbán N, Carrrió MM, Cuatrecasas S, Arís A, Villaverde A: Bacterial inclusion bodies are cytotoxic in vivo in absence of functional chaperones DnaK and GroEL. J Biotechnol 2005, 118:406-412.

162. Schneider EL, Thomas JG, Bassuk JA, Sage EH, Baneyx F: Manipulating the aggregation and oxidation of human SPARC in the cytoplasm of Escherichia coli. Nat Biotechnol 1997, 15:581-585.

163. Haslberger T, Zdanowicz A, Brand I, Kirstein J, Turgay K, Mogk A, Bukau B: Protein disaggregation by the AAA+ chaperone ClpB involves partial threading of looped polypeptide segments. Nat Struct Mol Biol 2008, 15(6):641-650.

164. Goenka S, Rao CM: Expression of recombinant zeta-crystallin in Escherichia coli with the help of GroEL/ES and its purification. Protein Expr Purif 2001, 21(2):260-267. 
165. Sareen D, Sharma R, Vohra RM: Chaperone-assisted overexpression of an active D-carbamoylase from Agrobacterium tumefaciens AM 10. Protein Expr Purif 2001, 23(3):374-379.

166. Nishihara K, Kanemori M, Yanagi H, Yura T: Overexpression of trigger factor prevents aggregation of recombinant proteins in Escherichia coli. Appl Environ Microbiol 2000, 66:884-889.

167. Yokoyama K, Kikuchi Y, Yasueda H: Overproduction of DnaJ in Escherichia coli improves in vivo solubility of the recombinant fish-derived transglutaminase. Biosci Biotechnol Biochem 1998, 62:1205-1210.

168. Rinas U, Hoffmann F, Betiku E, Estapé D, Marten S: Inclusion body anatomy and functioning of chaperone-mediated in vivo inclusion body disassembly during high-level recombinant protein production in Escherichia coli. J Biotechnol 2007, 127(2):244-257.

169. Nash HA, Robertson CA, Flamm E, Weisberg RA, Miller HI: Overproduction of Escherichia coli integration host factor, a protein with nonidentical subunits. J Bacteriol 1987, 169(9):4124-4127.

170. Chen HC, Hwang CF, Mou DG: High-density Escherichia coli cultivation process for hyperexpression of recombinant porcine growth hormone. Enzyme Microb Technol 1992, 14(4):321-326.

171. Gupta JC, Jaisani M, Pandey G, Mukherjee KJ: Enhancing recombinant protein yields in Escherichia coli using the T7 system under the control of heat inducible lambda PL promoter. J Biotechnol 1999, 68(2-3):125-134.

172. Shen YL, Zhang Y, Sun AY, Xia XX, Wei DZ, Yang SL: High-level production of soluble tumor necrosis factor-related apoptosis-inducing ligand (Apo2L/TRAIL) in high-density cultivation of recombinant Escherichia coli using a combined feeding strategy. Biotechnol Lett 2004, 26(12):981-984.

173. Mukherjee K, Rowe DC, Watkins NA, Summers DK: Studies of single-chain antibody expression in quiescent Escherichia coli. Appl Environ Microbiol 2004, 70(5):3005-3012.

174. Wen C, Gan R, Zhu S: Construction of secretory expression system suitable to express glucagon under the control of PL promoter. Curr Microbiol 2003, 47(3):180-185.

doi:10.1186/1475-2859-9-18

Cite this article as: Valdez-Cruz et al:: Production of recombinant proteins in $E$. coli by the heat inducible expression system based on the phage lambda $\mathrm{pL}$ and/or pR promoters. Microbial Cell Factories 2010 9:18.

\section{Submit your next manuscript to BioMed Central and take full advantage of:}

- Convenient online submission

- Thorough peer review

- No space constraints or color figure charges

- Immediate publication on acceptance

- Inclusion in PubMed, CAS, Scopus and Google Scholar

- Research which is freely available for redistribution 